\title{
Thermodynamic assessment of the La-Cr-O system
}

\section{Journal Article}

Author(s):

Povoden, E.; Chen, M.; Grundy, A.N.; Ivas, T.; Gauckler, Ludwig J.

Publication date:

2009

Permanent link:

https://doi.org/10.3929/ethz-b-000019054

Rights / license:

In Copyright - Non-Commercial Use Permitted

Originally published in:

Journal of phase equilibria and diffusion 30(1), https://doi.org/10.1007/s11669-008-9463-0 


\title{
Thermodynamic Assessment of the La-Cr-O System
}

\author{
E. Povoden, M. Chen, A.N. Grundy, T. Ivas, and L.J. Gauckler
}

(Submitted May 6, 2008; in revised form September 23, 2008)

\begin{abstract}
The La-Cr and the La-Cr-O systems are assessed using the Calphad approach. The calculated $\mathrm{La}-\mathrm{Cr}$ phase diagram as well as $\mathrm{LaO}_{1.5}-\mathrm{CrO}_{1.5}$ phase diagrams in pure oxygen, air, and under reducing conditions are presented. Phase equilibria of the La-Cr-O system are calculated at $1273 \mathrm{~K}$ as a function of oxygen partial pressure. In the $\mathrm{La}-\mathrm{Cr}$ system reported solubility of lanthanum in bec chromium is considered in the modeling. In the La-Cr-O system the Gibbs energy functions of $\mathrm{La}_{2} \mathrm{CrO}_{6}, \mathrm{La}_{2}\left(\mathrm{CrO}_{4}\right)_{3}$, and perovskite-structured $\mathrm{LaCrO}_{3}$ are presented, and oxygen solubilities in bcc and fcc metals are modeled. Emphasis is placed on a detailed description of the perovskite phase: the orthorhombic to rhombohedral transformation and the contribution to the Gibbs energy due to a magnetic order-disorder transition are considered in the model. The following standard data of stoichiometric perovskite are calculated: $\Delta_{\text {f,oxides }} H_{298 K}\left(\mathrm{LaCrO}_{3}\right)=-73.7 \mathrm{~kJ} \mathrm{~mol}^{-1}$, and ${ }^{\circ} S_{298 \mathrm{~K}}\left(\mathrm{LaCrO}_{3}\right)=109.2 \mathrm{~J} \mathrm{~mol}^{-1} \mathrm{~K}^{-1}$. The Gibbs energy of formation from the oxides, $\Delta_{\mathrm{f}, \text { oxides }}{ }^{\circ} \mathrm{G}\left(\mathrm{LaCrO}_{3}\right)=-72.403-0.0034 T$ $\left(\mathrm{kJ} \mathrm{mol}^{-1}\right)(1273-2673 \mathrm{~K})$ is calculated. The decomposition of the perovskite phase by the reaction $\mathrm{LaCrO}_{3} \rightarrow \frac{1}{2} \mathrm{La}_{2} \mathrm{O}_{3}+\mathrm{Cr}+\frac{3}{4} \mathrm{O}_{2}(\mathrm{~g}) \uparrow$ is calculated as a function of temperature and oxygen partial pressure: at $1273 \mathrm{~K}$ the oxygen partial pressure of the decomposition, $p_{\mathrm{O}_{2}(\text { decomp })}=10^{-20.97} \mathrm{~Pa}$. Cation nonstoichiometry of $\mathrm{La}_{1-x} \mathrm{CrO}_{3}$ perovskite is described using the compound energy formalism (CEF), and the model is submitted to a defect chemistry analysis. The liquid phase is modeled using the two-sublattice model for ionic liquids.
\end{abstract}

Keywords defect chemistry, $\mathrm{LaCrO}_{3}$, lanthanum chromate, SOFC

\section{Introduction}

In solid oxide fuel cells (SOFC), the thermodynamic stability of the cathode is particularly important for efficient long-term operation. Sr-doped lanthanum manganites (LSM) with the perovskite structure are used as cathode materials in SOFC. Diffusion of chromium from the metallic interconnect with high chromium content into the cathode leads to the formation of $\mathrm{Mn}(\mathrm{Cr}, \mathrm{Mn})_{2} \mathrm{O}_{4}$ spinel and $\mathrm{Cr}_{2} \mathrm{O}_{3}$ along with a severe cell voltage decrease. ${ }^{[1-4]}$ As the thermal expansions of $\mathrm{LaCrO}_{3}$-based interconnect and conventional perovskite cathode materials are similar, and $\mathrm{Cr}$-diffusion into the cathode from $\mathrm{LaCrO}_{3}$-based interconnects is significantly lower than from Cr-containing metallic interconnects, recently Sr-, V-doped ${ }^{[5]}$ and $\mathrm{Zn}$-doped ${ }^{[6]}$ $\mathrm{La}_{1-x} \mathrm{Ca}_{x} \mathrm{CrO}_{3-\delta}$ have been considered as promising alternative interconnect materials for SOFC. Furthermore alkaline earth containing $\mathrm{LaCrO}_{3}$ has been proposed as a cathode material in a recent study by Jiang et al. ${ }^{[7]}$

E. Povoden, T. Ivas, and L.J. Gauckler, Nonmetallic Inorganic Materials, ETH Zurich, Zurich, Switzerland; M. Chen, Fuel Cells and Solid State Chemistry Department, Risø National Laboratory, Technical University of Denmark, Roskilde, Denmark; A.N. Grundy, Concast AG, Zurich, Switzerland. Contact e-mail: Erwin.povoden@mat.ethz.ch.
The present thermodynamic assessment of the $\mathrm{La}-\mathrm{Cr}-\mathrm{O}$ system lays the groundwork for extension to a thermodynamic La-Sr-Mn-Cr-O oxide database that is required to understand the thermodynamics of SOFC degradation by chromium. It is also a starting point for extensions to thermodynamic databases with additional components serving as dopants in $\mathrm{LaCrO}_{3}$ for SOFC interconnect and cathode applications.

The assessment of the La-Cr-O system using the Calphad approach is based on the recently reassessed $\mathrm{La}_{-} \mathrm{O}^{[8]}$ and Cr-O subsystems. ${ }^{[9]}$ The lattice stabilities of elements are adopted from Dinsdale. ${ }^{[10]}$ All available experimental phase diagram, thermodynamic, and structure-chemical data are critically assessed, aiming at minimizing the squared errors between experiments and calculation during the optimization of model parameters using the PARROT module of the Thermocalc ${ }^{[11]}$ software.

\section{Literature Review of the La-Cr System}

The La-Cr system has a eutectic at $1138 \mathrm{~K}^{[12,13]}$ and 3.4 at. $\% \mathrm{Cr}^{[13]}$ and a monotectic at $1983 \mathrm{~K}^{[12]}$ or $2103 \mathrm{~K}^{[14]}$ and 96 at. $\%^{[12]}$ or 99.1 at. $\%^{[14]} \mathrm{Cr}$, as well as a large liquidliquid miscibility gap. ${ }^{[12,13]}$ No intermetallic phases were found in the La-Cr system. ${ }^{[12,13]}$

Berezutskii et al. ${ }^{[15]}$ determined the partial enthalpy of mixing in La-Cr liquid with infinite dilution of $\mathrm{Cr}, \Delta \bar{H}_{\mathrm{Cr}}$ at $1700 \mathrm{~K}$ using high-temperature calorimetry.

As small additions of rare-earth metals essentially increase the high-temperature corrosion resistance of chromium, ${ }^{[16]}$ modeling of the La-solubility in bcc-structured $\mathrm{Cr}$, denoted as $\alpha \mathrm{Cr}_{\mathrm{ss}}$, is of technological interest. Small 
solubility of $\mathrm{La}$ in $\alpha \mathrm{Cr}_{\mathrm{ss}}$ was reported,${ }^{[12,14,17]}$ whereas $\mathrm{Cr}$ is almost insoluble in La. ${ }^{[13]}$ The solubility of $\mathrm{La}$ in $\alpha \mathrm{Cr}_{\mathrm{ss}}$ was determined in investigations by Savitskii et al ${ }^{[12]}$ from $1073 \mathrm{~K}$ up to the melting of $\mathrm{Cr}$ using metallographic and micro-hardness techniques to be 2.5 at.\% at $1983 \mathrm{~K}$. Svechnikov et al. ${ }^{[14]}$ reported a La solubility of 0.68 at.\% at $2103 \mathrm{~K}$, and Epstein et al. ${ }^{[17]}$ found $\mathrm{La}<0.04$ at.\% in $\alpha \mathrm{Cr}_{\mathrm{ss}}$ at $1533 \mathrm{~K}$. The solubility of La in $\alpha \mathrm{Cr}_{\mathrm{ss}}$ decreases toward lower temperatures.

\section{Literature Review of the La-Cr-O System}

In the $\mathrm{LaO}_{1.5}-\mathrm{CrO}_{1.5}$ system two eutectics were found at 19 at. $\% \mathrm{Cr}_{2} \mathrm{O}_{3}(T=2243 \mathrm{~K})^{[18]}$ or 12 at. $\% \mathrm{Cr}_{2} \mathrm{O}_{3}(T=$ $2323 \pm 20 \mathrm{~K}),{ }^{[19]}$ and at 84 at. $\% \mathrm{Cr}_{2} \mathrm{O}_{3}(T=2248 \mathrm{~K})^{[18]}$ or 80 at. $\% \mathrm{Cr}_{2} \mathrm{O}_{3}(T=2473 \pm 20 \mathrm{~K})^{[29]}$ in argon atmosphere on either side of the congruently melting perovskitestructured lanthanum chromite ${ }^{[18-20]}$ (in this study oxides containing $\mathrm{Cr}$ (III) and $\mathrm{Cr}$ with higher valencies than three are denoted as chromite and chromate respectively). The melting temperature of lanthanum chromite in air, $T_{\mathrm{m}}$ (air) $=2773 \mathrm{~K}$ was determined by Foëx ${ }^{[21]}$ and by Coutures et al. $^{[20]}$ using a thermal analysis technique described in more detail in earlier publications. ${ }^{[22-24]}$ The melting temperature was measured with optical pyrometers. $T_{\mathrm{m}}(\operatorname{argon})=2703 \mathrm{~K}$ was reported by Tresvjatskiy et al., ${ }^{[18]}$ but in the graphic presentation of the phase diagram in the same paper $T_{\mathrm{m}}(\operatorname{argon}) \approx 2600 \mathrm{~K}$, and the exact value of the oxygen partial pressure was not specified. Experimentally determined special points in the $\mathrm{LaO}_{1.5}-\mathrm{CrO}_{1.5}$ quasibinary system reveal a considerable spread. This is not surprising as experiments are complicated due to the high investigation temperatures and evaporation predominantly of $\mathrm{Cr}^{[25,26]}$ Furthermore deviations between the data from Tresvjatskiy et al. ${ }^{[18]}$ and Berjoan ${ }^{[19]}$ may partly originate from differences of the oxygen partial pressure, which in both studies was not specified exactly. The peritectic phase diagram proposed by Cassedanne ${ }^{[27]}$ is in gross conflict with the phase diagram data from the other groups.

Experimental oxygen solubilities in pure $\mathrm{Cr}$ and $\mathrm{La}$ were considered in thermodynamic assessments by Povoden et al. ${ }^{[9]}$ and Grundy et al., ${ }^{[28]}$ but experiments on oxygen solubilities in $\alpha \mathrm{Cr}_{\mathrm{ss}}$ are missing.

\subsection{Lanthanum Chromates}

The following lanthanum chromates were documented: Berjoan ${ }^{[19]}$ reported that orthorhombic $\mathrm{La}_{2} \mathrm{CrO}_{6}$ forms at $T>923 \mathrm{~K}$. Using differential scanning calorimetry (DSC) he determined the enthalpy change of the reaction

$2 \mathrm{La}_{2} \mathrm{O}_{3}+\mathrm{Cr}_{2} \mathrm{O}_{3}+\frac{3}{2} \mathrm{O}_{2(\mathrm{~g})} \rightarrow 2 \mathrm{La}_{2} \mathrm{CrO}_{6}$

at $1055 \mathrm{~K}$ and $p_{\mathrm{O}_{2}}=83,000 \mathrm{~Pa}$ to be $-151 \pm 8 \mathrm{~kJ} \mathrm{~mol}^{-1}$.

The enthalpy of formation of $\mathrm{La}_{2}\left(\mathrm{CrO}_{4}\right)_{3}$ from the elements at $298 \mathrm{~K}$ was proposed by Tsyrenova et al. ${ }^{[29]}$ to be $-3961 \pm 11.7 \mathrm{~kJ} \mathrm{~mol}^{-1}$. $\mathrm{La}_{2}\left(\mathrm{CrO}_{4}\right)_{3}$ decomposes by

$$
\mathrm{La}_{2}\left(\mathrm{CrO}_{4}\right)_{3} \stackrel{890-1030 \mathrm{~K}}{\longrightarrow} 2 \mathrm{LaCrO}_{3}+0.5 \mathrm{Cr}_{2} \mathrm{O}_{3}+2.25 \mathrm{O}_{2(\mathrm{~g})} \uparrow
$$

An enthalpy change of $231 \mathrm{~kJ} \mathrm{~mol}^{-1}$ was determined for this reaction at the average temperature of $960 \mathrm{~K}^{[30]}$

$\mathrm{LaCrO}_{4}$ has been interpreted as a mixed-valent intermediate decomposition product of $\mathrm{La}_{2}\left(\mathrm{CrO}_{4}\right)_{3} \cdot{ }^{[30,31]}$

Stoichiometries and thermal stability ranges of lanthanum chromates with complex formulae were reported by Berjoan et al. ${ }^{[32]}$ However these were in significant disagreement with later results obtained by the same author. ${ }^{[19]}$

\subsection{The Perovskite Phase}

Existing experimental data of lanthanum chromite perovskite structure, ${ }^{[33-45]}$ thermodynamics, ${ }^{[30,33-35,43,46-53]}$ phase stability, ${ }^{[54]}$ and nonstoichiometry ${ }^{[55,56]}$ along with the investigation techniques used are listed in Table 1.

\subsection{Crystal and Magnetic Structure}

$\mathrm{LaCrO}_{3}$ is orthorhombic at room temperature and transforms to rhombohedral structure at higher temperatures. ${ }^{[20,33-42]}$ Both the rhombohedral and orthorhombic forms of $\mathrm{LaCrO}_{3}$ are slight distortions of the perovskite crystal structure. The perovskite structure is primitive cubic and with the formula $\mathrm{ABX}_{3}$ and has an $\mathrm{A}$ atom at the unit cell origin, $(0,0,0)$, a $\mathrm{B}$ atom at the body-centered position $(1 / 2,1 / 2,1 / 2)$, and three $X$ atoms at the face-centered positions, $(1 / 2,1 / 2,0 ; 1 / 2,0,1 / 2,1 / 2,0,1 / 2,1 / 2)$. The body diagonal of the unit cell, [111], exhibits threefold rotational symmetry and has a magnitude of $3 \frac{1}{2}$ [a] where a is the lattice parameter. Any deviation of this dimension away from $3 \frac{1}{2}$ [a] retains the threefold rotational symmetry and the equality of the three lattice parameters, but reduced the angles between the lattice parameters to less than $90^{\circ}$ for a length $>31 / 2$ [a] or greater than $90^{\circ}$ for a length $<3 \frac{1}{2}$ [a]. Thus the symmetry in either case becomes rhombohedral. Similarly, if the perovskite until cell is distorted in such a way that one lattice parameter is shortened, a second is lengthened, and the third remains the same with retention of the $90^{\circ}$ interaxial angles, the symmetry becomes orthorhombic. For both distortions, the atomic loci are retained with $\mathrm{La}$ at the cell origin, $\mathrm{Cr}$ at the body-centered site, and $\mathrm{O}$ at the three-face centered positions. ${ }^{[57]}$ In the present paper, the Gibbs energy expressions for the two different forms are distinguished by superscripting with r-prv or o-prv.

The temperatures, enthalpy and entropy changes of this first-order ${ }^{[4]}$ transition taken from the literature are listed in Table 2 along with the investigation techniques used. The reported transformation temperatures lie between 503 and $583 \mathrm{~K}$. The determined enthalpy and entropy changes vary from 277 to $502.08 \mathrm{~J} \mathrm{~mol}^{-1}$ and 0.5 to $0.96 \mathrm{~J} \mathrm{~mol}^{-1} \mathrm{~K}^{-1}$. A transformation from rhombohedral to cubic structure at a temperature close to $1300 \mathrm{~K}$ was reported by Ruiz et al. ${ }^{[37]}$ and Momin et al., ${ }^{[41]}$ whereas Coutures et al. ${ }^{[20]}$ reported $1923 \mathrm{~K}$ using high-temperature X-ray diffraction (HTXRD), in agreement with Berjoan ${ }^{[19]}(1923 \pm 20 \mathrm{~K})$ using dilatometry. Berjoan ${ }^{[19]}$ further reported prevailing of the cubic structure at $2173 \mathrm{~K}$. On the other hand Geller and 
Table 1 Calculated and experiment thermodynamic data of La-Cr oxides

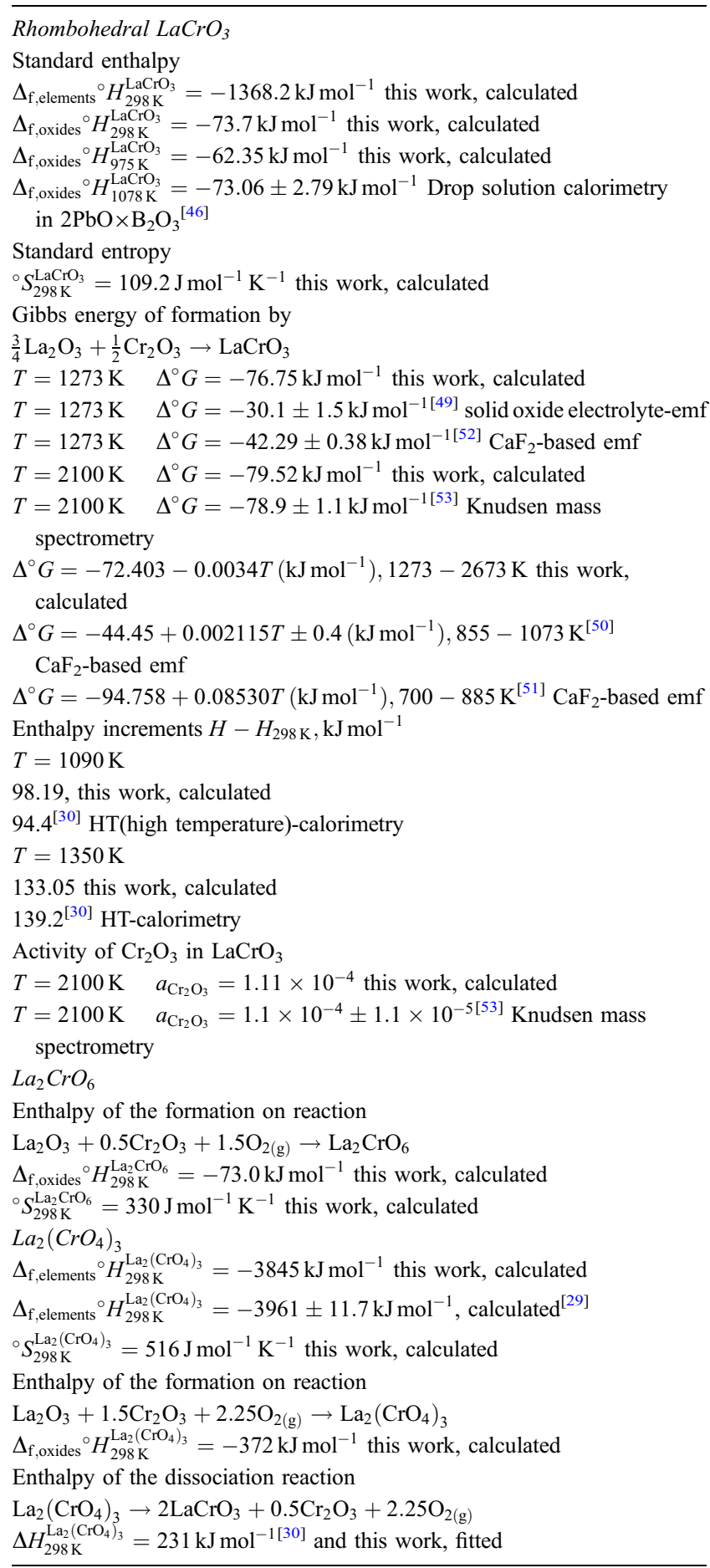

Raccah $^{[38]}$ as well as Höfer and $\mathrm{Kock}^{[34]}$ did not observe the rhombohedral to cubic transition up to $T=1873 \mathrm{~K}$ and $T=1823 \mathrm{~K}$ respectively using differential thermal analysis (DTA).

A magnetic order-disorder transition was documented to occur at $T \approx 287 \mathrm{~K},{ }^{[35]} 289 \mathrm{~K},,^{[45]}$ or $295 \mathrm{~K}^{[46]}$
Table 2 Calculated and experimental data of the orthorhombic $\rightarrow$ rhombohedral transition of $\mathrm{LaCrO}_{3}$

Transition temperature, $\mathrm{K}$

540 , this work, calculated

$503-583^{[33]}$ adiabatic calorimetry

$544 \pm 1^{[34]}$ (a) DTA, DSC, thermogravimetry, dilatometry

$536^{[35]}$ (a) adiabatic shield calorimetry, HT-XRD (air and vacuum)

$563 \pm 5^{[36]}$ DTA, dilatometry, HT-XRD, HT-microscopy, HT-X-ray

photography

$550^{[37]}$ HT-XRD

$528-533^{[38]}$ (a) HT-XRD

$533 \pm 3^{[38]}$ (a) DTA

$543^{[39]}$ XRD

$533^{[20]}$ HT-XRD

$540 \pm 2^{[40]}$ (a) HT-XRD, DSC

$533 \pm 5^{[40]}$ (a) HT-XRD, dilatometry

$545^{[41]}$ heating, DSC

$535^{[41]}$ cooling DSC

$550^{[41]}$ HT-XRD

$523^{[42]}$ (a) starting transition, simultaneous DSC-XRD

$541^{[42]}$ (a) completed transition, simultaneous DSC-XRD

$533^{[43]}$ estimated from neutron powder diffraction

$509^{[44]}$ DSC, XRD

Enthalpy change of transition, $\mathrm{J} \mathrm{mol}^{-1}$

340 , this work, calculated

$502.08 \pm 41.84$ at $503-583 \mathrm{~K}^{[33]}$ calculated from adiabatic calorimetry

277 at $544 \pm 1 \mathrm{~K}^{[34]}$ (a) DSC

403.25 at $536^{[35]}$ (a) calculated from adiabatic shield calorimetry

$340 \pm(10-40)$ at $533 \pm 5^{[40]}$ (a) DSC

380 at $550 \mathrm{~K}^{[41]}$ DSC

310 at $509 \mathrm{~K}^{[44]}$ DSC

Enthalpy change of transition, $\mathrm{J} \mathrm{mol}^{-1} \mathrm{~K}^{-1}$

0.63 , this work, calculated

0.96 at $503-583 \mathrm{~K}^{[33]}$ calculated from adiabatic calorimetry

$0.5^{[34]}$ (a) calculated from DSC

$0.75^{[35]}$ (a) calculated from adiabatic shield calorimetry

(a) Used for optimization

\subsection{Enthalpy of Formation}

Cheng and Navrotsky ${ }^{[47]}$ determined the enthalpy of formation of $\mathrm{LaCrO}_{3}$ by oxide melt solution calorimetry at $1078 \mathrm{~K}$.

\subsection{Heat Capacity and Enthalpy Increment Data}

The heat capacities of $\mathrm{LaCrO}_{3}$ were measured by Korobeinikova and Reznitskii ${ }^{[33]}$ from 340 to $900 \mathrm{~K}$ using adiabatic calorimetry, Höfer and $\mathrm{Kock}^{[34]}(480-610 \mathrm{~K})$ and Satoh et al. ${ }^{[45]}(150-450 \mathrm{~K})$ using DSC, Satoh et al. ${ }^{[45]}$ (77$280 \mathrm{~K})$ using alternating current calorimetry, Sakai et al. ${ }^{[35]}$ (100-1000 K) using laser-flash calorimetry, and Sakai and Stølen $^{[43]}$ (272-1000 K) using adiabatic shield calorimetry. Enthalpy increments of $\mathrm{LaCrO}_{3}$ at 1090 and $1350 \mathrm{~K}$ were measured by Suponitskii ${ }^{[30]}$ using a high-temperature heatconducting calorimeter. 


\subsection{Gibbs Energy of Formation}

In order to obtain the Gibbs energy of formation of $\mathrm{LaCrO}_{3}$, Chen et al. ${ }^{[49]}$ measured electromotive force (emf) of the solid oxide galvanic cell $\mathrm{Pt} / \mathrm{Cr}, \mathrm{La}_{2} \mathrm{O}_{3}, \mathrm{LaCrO}_{3} / \mathrm{MgO}-$ stabilized $\mathrm{ZrO}_{2} / \mathrm{Cr}_{2} \mathrm{O}_{3}, \mathrm{Cr} / \mathrm{Pt}$ at $1273 \mathrm{~K}$. Azad et al., ${ }^{[50]}$ Chen et al. ${ }^{[51]}$ and Dudek et al. ${ }^{[52]}$ measured emf of Pt, $\mathrm{O}_{2} /$ $\mathrm{La}_{2} \mathrm{O}_{3}, \mathrm{LaF}_{3} / \mathrm{CaF}_{2} / \mathrm{LaF}_{3}, \mathrm{LaCrO}_{3}, \mathrm{Cr}_{2} \mathrm{O}_{3} / \mathrm{O}_{2}$, Pt in pure oxygen from 855 to $1073 \mathrm{~K}, 700$ to $885 \mathrm{~K}$, and $1273 \mathrm{~K}$ respectively. Peck et al. ${ }^{[53]}$ derived the Gibbs energy of formation of $\mathrm{LaCrO}_{3}$ from the determination of the thermodynamic activity of $\mathrm{Cr}_{2} \mathrm{O}_{3}$ in $\mathrm{LaCrO}_{3}$ for the $\mathrm{Cr}_{2} \mathrm{O}_{3}$-poor phase boundary of $\mathrm{LaCrO}_{3}$ in the temperature range from 1887 to $2333 \mathrm{~K}$ using Knudsen effusion mass spectrometry.

\subsection{Chemical Stability}

Nakamura et al. ${ }^{[54]}$ reported no weight loss of lanthanum chromite at $1273 \mathrm{~K}$ from pure oxygen to $p_{\mathrm{O}_{2}}=10^{-16.1} \mathrm{~Pa}$ using thermogravimetry combined with $\mathrm{X}$-ray diffraction (XRD). This means that the perovskite phase does not decompose within this oxygen partial pressure range, and its oxygen nonstoichiometry is neglectable.

\subsection{Cation Nonstoichiometry and Defect Chemistry}

Maximum excess $\mathrm{Cr}$ in single-phase $\mathrm{La}_{1-x} \mathrm{CrO}_{3}$ of 0.38 at.\% in furnace-cooled $\mathrm{LaCrO}_{3}$ annealed at $1773 \mathrm{~K}$ in air was reported from Khattak and Cox. ${ }^{[55]}$ Single phase lanthanum chromite with 0.76-1.28 at.\% excess $\mathrm{Cr}$ was prepared at $1773 \mathrm{~K}$ in a pure oxygen atmosphere. ${ }^{[56]}$ Iliev et al. ${ }^{[56]}$ observed an intensity decrease of the high frequency band in a Raman spectrum of lanthanum chromite measured after annealing the phase in vacuum at $1273 \mathrm{~K}$. This feature was assigned to a reduced number of $\mathrm{Cr}^{4+}$ due to partial removal of oxygen during the annealing of the originally lanthanum-deficient perovskite phase.

Interpretations of the defect chemistry of the perovskite phase were made from electrical conductivity measurements: the electrical conduction in lanthanum chromite is almost purely electronic, ${ }^{[37,58]}$ affirming the lack of oxygen vacancies in the structure, in line with the results from thermogravimetry. ${ }^{[54]}$ Ruiz et al. ${ }^{[37]}$ reported that the ionic transport number in lanthanum chromite is less than $0.05 \%$ up to $1250 \mathrm{~K}$. Akashi et al. ${ }^{[59]}$ measured the isothermal electrical conductivity of an equilibrated $\mathrm{La}_{1-x} \mathrm{CrO}_{3}-\mathrm{Cr}_{2} \mathrm{O}_{3}$ mixture with 5 vol.\% excess $\mathrm{Cr}_{2} \mathrm{O}_{3}$ at $1573-1673 \mathrm{~K}$ from $p_{\mathrm{O}_{2}}=1.0 \times 10^{3} \mathrm{~Pa}$ to $p_{\mathrm{O}_{2}}=2.0 \times 10^{4} \mathrm{~Pa}$. They observed an extraordinarily slow equilibration of the samples: More than four months were required to measure the electrical conductivity at equilibrium state. The conductivity was proportional to $p_{\mathrm{O}_{2}}{ }^{3 / 16}$, the same as reported in an earlier study. ${ }^{[25]}$ On the other hand a slope of $p_{\mathrm{O}_{2}}{ }^{1 / 4}$ from 700 to $1300 \mathrm{~K}$ and purely intrinsic conductivity $>1600 \mathrm{~K}$ stated by Shvaiko-Shvaikovskii et al. ${ }^{[58]}$ is inconsistent with the findings from Akashi et al. ${ }^{[58]}$ Shvaiko-Shvaikovskii et al. ${ }^{[58]}$ deduced $n$-type conductivity from measurements of transport number, resistivity and thermo-emf at $p_{\mathrm{O}_{2}}=1 \mathrm{~Pa}$ and $p_{\mathrm{O}_{2}}=10^{2} \mathrm{~Pa}$, the electrical conductivity being proportional to $p_{\mathrm{O}_{2}}^{-3 / 8}$. The transition from reduced to stoichiometric chromite was accompanied by a decrease of about $0.1 \%$ in weight, thus the presence of interstitial $\mathrm{Cr}$ in reduced chromite was proposed. However $n$-type conductivity was not confirmed by any further study.

Several groups ${ }^{[59,60]}$ agree that the electrical neutrality is maintained by holes and lanthanum vacancies, and that the carrier is the hole in lanthanum chromite. ${ }^{[25,59-61]}$ Akashi et al. ${ }^{[59]}$ reported that concentrations of lanthanum vacancies and holes slightly increase from 1550 to $1700 \mathrm{~K}$. In contrast to the other authors Shvaiko-Shvaikovskii et al. ${ }^{[58]}$ and Meadowcroft ${ }^{[25]}$ proposed the occurrence of chromium vacancies instead of lanthanum vacancies.

\section{Thermodynamic Modeling and Optimization}

\subsection{Metal Phases}

In order to account for the solubility of $\mathrm{La}$ in $\alpha \mathrm{Cr}_{\mathrm{ss}}$, the zeroth-order, composition-independent interaction parame$\operatorname{ter}^{[62]}{ }^{0} L_{\mathrm{Cr} \text {.La:Va }}^{\mathrm{bcc}}$ was given a positive value. We chose the solubility values from Svechnikov et al. ${ }^{[14]}$ for its optimization, as these data are more comparable to solubilities in other rare earths-transition elements systems.

Povoden et al. ${ }^{[9]}$ described the solubility of oxygen in $\mathrm{Cr}(\mathrm{bcc})$ using the model $\mathrm{Cr}(\mathrm{Va}, \mathrm{O})_{3}$. For the reasons discussed recently, ${ }^{[63]}$ we reassess the oxygen-solubility in $\mathrm{Cr}(\mathrm{bcc})$ using the model $(\mathrm{Cr})(\mathrm{O}, \mathrm{Va})_{1.5}$, and $\alpha \mathrm{Cr}_{\mathrm{ss}}$ is then given by the two-sublattice description $(\mathrm{La}, \mathrm{Cr})(\mathrm{Va}, \mathrm{O})_{1.5}$. The Gibbs energy of the end-member $(\mathrm{Cr})(\mathrm{O})_{1.5}$ is defined as

$$
\begin{aligned}
{ }^{\circ} G_{(\mathrm{Cr})(\mathrm{O})_{1.5}}-H_{\mathrm{Cr}}^{\mathrm{SER}}-\frac{3}{2} H_{\mathrm{O}}^{\mathrm{SER}}= & { }^{\circ} G_{\mathrm{Cr}(\mathrm{bcc})}{ }^{[10]}+\frac{3}{4}{ }^{\circ} G_{\mathrm{O}_{2}}^{\mathrm{gas}[10]} \\
& +A+B T
\end{aligned}
$$

$H_{x}^{\mathrm{SER}}$ is the standard enthalpy of the stable state of element $x$ at $298.15 \mathrm{~K}$ and $10^{5} \mathrm{~Pa}^{[10]} A$ and $B$ are adjustable parameters; using the PARROT module of the Thermocalc software ${ }^{[11]} A$ was given the fixed value 0 for the reasons discussed in an earlier paper, ${ }^{[9]}$ while $B$ and a regular interaction parameter ${ }^{0} L_{\mathrm{Cr}: \mathrm{O}, \mathrm{Va}}$ were optimized with the same experimental data. ${ }^{[9]}$ Due to the lack of experimental data the oxygen solubility in $\alpha \mathrm{Cr}_{\mathrm{ss}}$ was modeled as an ideal extension of the oxygen solubilities in pure $\mathrm{La}$ and $\mathrm{Cr}$.

\subsection{Solid Oxides}

4.2.1 Lanthanum Chromates. The Gibbs energy function of $\mathrm{La}_{2} \mathrm{CrO}_{6}$ was based on the sum of the Gibbs energy functions of $\mathrm{La}_{2} \mathrm{O}_{3}, \mathrm{Cr}_{2} \mathrm{O}_{3}$, and $\mathrm{O}_{2}$ in proper stoichiometries and $A+B T$ parameters that were fitted to the enthalpy of formation from the oxides, Eq 1 as well as thermal stability data. The thermal stability of $\mathrm{La}_{2} \mathrm{CrO}_{6}$ is slightly influenced by the thermodynamics of the intermediate, mixed-valent chromates mentioned above. In order to refine the model parameters of $\mathrm{La}_{2} \mathrm{CrO}_{6}$, it was thus necessary to consider these mixed-valent chromates in a provisional version of the thermodynamic $\mathrm{La}-\mathrm{Cr}-\mathrm{O}$ database in spite of their arguable stoichiometries, and to optimize their model parameters with phase diagram data. ${ }^{[19,32]}$ The formation of chromates that contain mixed $\mathrm{Cr}$ valences may be explained by gradual reduction of $\mathrm{Cr}^{6+}$ in $\mathrm{La}_{2} \mathrm{CrO}_{6}$ as the temperature increases. 
These chromates can be interpreted as intermediate products in the scope of a sluggish decomposition of $\mathrm{La}_{2} \mathrm{CrO}_{6}$, which starts at $1153 \mathrm{~K}^{[19,32]}$ and is completed at $1473 \mathrm{~K}^{[32]}$ or $1523 \mathrm{~K}^{[19]}$ The simplified decomposition reaction reads

$$
\begin{aligned}
\mathrm{La}_{2} \mathrm{CrO}_{6} \stackrel{\text { mixed-valent chromates }{ }^{[19,32]}}{\longrightarrow} & \frac{1+x}{2} \mathrm{La}_{2} \mathrm{O}_{3}+\mathrm{La}_{1-x} \mathrm{CrO}_{3} \\
& +\frac{1.5-(1.5 x)}{2} \mathrm{O}_{2}(\mathrm{~g}) \uparrow
\end{aligned}
$$

Slight differences of the oxygen partial pressure during experiments may be reflected by a variable extent of $\mathrm{Cr}$ reduction, and consequently ambiguous stoichiometries of mixed-valent intermediate chromates. These lanthanum chromates with conflicting stoichiometries ${ }^{[19,32]}$ are not included in the presented thermodynamic database.

The Gibbs energy function of $\mathrm{La}_{2}\left(\mathrm{CrO}_{4}\right)_{3}$ was formulated using the same strategy as for $\mathrm{La}_{2} \mathrm{CrO}_{6}$. The model parameters were fitted to the experimental enthalpy and temperature of decomposition. ${ }^{[30]}$ The enthalpy of formation from the elements ${ }^{[29]}$ was not used as it is a calculated value.

We go along with the interpretation of $\mathrm{LaCrO}_{4}$ being an intermediate reaction product during the decomposition of $\mathrm{La}_{2}\left(\mathrm{CrO}_{4}\right)_{3}$ by Eq 2 and do not include this phase in the modeling.

4.2.2 The Perovskite Phase. GVCR4O and GLCR4O stand for the Gibbs energy functions of the completely oxidized neutral endmember. GVCR4O and GLCR4O are set equal for orthorhombic and rhombohedral perovskite at the transition. Stoichiometric perovskite: The Gibbs energy function of stoichiometric rhombohedral $\mathrm{LaCrO}_{3}$ with the sublattice formula $\left(\mathrm{La}^{3+}\right)\left(\mathrm{Cr}^{3+}\right)\left(\mathrm{O}^{2-}\right),{ }^{\circ} \mathrm{G}_{\mathrm{LaCrO}_{3}}^{\mathrm{r}-\mathrm{prv}}$ is given by

$$
\begin{aligned}
&{ }^{\circ} G_{\mathrm{LaCrO}_{3}}^{\mathrm{r}-\mathrm{prv}}-H_{\mathrm{La}}^{\mathrm{SER}}-H_{\mathrm{Cr}}^{\mathrm{SER}}-3 H_{\mathrm{O}}^{\mathrm{SER}}={ }^{\circ} G_{\mathrm{La}^{3+}: \mathrm{Cr}^{3+}: \mathrm{O}^{2-}} \\
&=\mathrm{GRPRV}= \frac{1}{2}{ }^{\circ} G_{\mathrm{Cr}_{2} \mathrm{O}_{3}}{ }^{[9]}+\frac{1}{2}{ }^{\circ} G_{\mathrm{La}_{2} \mathrm{O}_{3}}{ }^{[8]}+G_{\mathrm{mag}}+A+B T \\
&+C T \ln T
\end{aligned}
$$

The parameters $A, B$, and $C$ are optimized using the enthalpy of formation from Cheng and Navrotsky, ${ }^{[4]}$ activity-data of $\mathrm{Cr}_{2} \mathrm{O}_{3}$ in $\mathrm{LaCrO}_{3}$ from Peck et al., ${ }^{[53]}$ heat capacity-data obtained by adiabatic calorimetry from Sakai and Stølen, ${ }^{[35]}$ and enthalpy increment-data measured at high temperatures. ${ }^{[30]}$ A phase diagram with congruent melting of lanthanum chromite and two eutectics ${ }^{[18,19]}$ cannot be reproduced by using the emf-experiments. ${ }^{[49-52]}$ Thus these data were excluded from the optimization.

$A+B T$ parameters of the low-temperature orthorhombic perovskite phase were optimized with those temperatures, ${ }^{[34,35,38,40,42]}$ enthalpies ${ }^{[34,35,40]}$ and entropies ${ }^{[34,35]}$ of transition having been obtained by combined investigation techniques and being internally most consistent. The rhombohedral to cubic transformation at high temperatures is not considered in the model, as there is no existing thermodynamic data for this transition.

Cation-nonstoichiometric perovskite: to choose a proper model for nonstoichiometric perovskite the following considerations are made: the formation of interstitial $\mathrm{Cr}$ in lanthanum chromite proposed by Shvaiko-Shvaikovskii et al. ${ }^{[58]}$ is unlikely due to the densely-packed perovskite structure, and oxygen nonstoichiometry can be excluded from thermogravimetry ${ }^{[54]}$ and electrical conductivity ${ }^{[37,59]}$ measurements. Thus the defects in $n$-type conducting ${ }^{[58]}$ lanthanum chromite are ambiguous and were not considered in the model.

B-site vacancies are energetically less favored than A-site vacancies in the perovskite structure. ${ }^{[64,65]}$ This means that the simplest sublattice model to describe cation nonstoichiometric $\mathrm{La}_{1-x} \mathrm{CrO}_{3}$ reads $\left(\mathrm{La}^{3+}, \mathrm{Va}\right)\left(\mathrm{Cr}^{3+}, \mathrm{Cr}^{4+}\right)\left(\mathrm{O}^{2-}\right)_{3}$. While this model results in a satisfying reproduction of experimental data, irreconcilable trouble is encountered at the extension to the $\mathrm{LaO}_{1.5}-\mathrm{MnO}_{1.5}-\mathrm{CrO}_{1.5}$ system required for SOFC applications due to diversities between the model descriptions of lanthanum chromite and lanthanum manganite. ${ }^{[66]}$ These are solved by allowing Va on the B-site and the anion sublattice of lanthanum chromite just like in lanthanum manganite ${ }^{[66]}$ leading to the appropriate sublattice formula $\left(\mathrm{La}^{3+}, \mathrm{Va}\right)\left(\mathrm{Cr}^{3+}, \mathrm{Cr}^{4+}, \mathrm{Va}\right)\left(\mathrm{O}^{2-}, \mathrm{Va}\right)_{3}$. The optimization of selective model parameters listed in Table 3 resulted in negligible concentrations of $\mathrm{Va}$ on the B-site and the anion sublattice, and the perovskite formula essentially remains $\mathrm{La}_{1-x} \mathrm{CrO}_{3}$. Using the compound energy formalism $(\mathrm{CEF})^{[67-69]}$ the molar Gibbs energy of $\mathrm{La}_{1-x} \mathrm{CrO}_{3}$ reads

$$
\begin{aligned}
{ }^{\circ} G_{\mathrm{m}}^{\mathrm{prv}}= & \sum_{i} \sum_{j} \sum_{k} y_{i} y_{j} y_{k}{ }^{\circ} G_{i: j: k} \\
& +R T\left(\sum_{i} y_{i} \ln y_{i}+\sum_{j} y_{j} \ln y_{j}+\sum_{k} y_{k} \ln y_{k}\right) \\
& +{ }^{\mathrm{E}} G_{\mathrm{m}}^{\mathrm{prv}}+G_{\mathrm{mag}}
\end{aligned}
$$

where $y_{i}$ is the site fraction of $\mathrm{Va}$ and $\mathrm{La}^{3+}$ on the A-sublattice, $y_{j}$ is the site fraction of $\mathrm{Cr}^{3+}, \mathrm{Cr}^{4+}$ and $\mathrm{Va}$ on the B-sublattice, and $y_{k}$ is the site fraction of $\mathrm{O}^{2-}$ and $\mathrm{Va}$ on the anion sublattice of the perovskite $\mathrm{A}_{1-x} \mathrm{BO}_{3}$. $R=8.31451 \mathrm{~J} \mathrm{~mol}^{-1} \mathrm{~K}^{-1}$. The third-last term accounts for the configurational entropy of mixing. The second-last term describes the excess Gibbs energy of mixing due to interactions of ions in the mixture. These are accounted for by the optimization of interaction parameters. The last term designates the magnetic contribution to the Gibbs energy. For the magnetic part of the Gibbs energy a magnetic ordering-model proposed by Inden ${ }^{[70]}$ and simplified by Hillert and Jarl ${ }^{[71]}$ was used. A short summary of this model can be found in Chen et al. ${ }^{[72]}$ The magnetic parameters $T_{\mathrm{c}}$ and $\beta$ were fitted to the $C_{p}$-data around the magnetic transition temperature from Sakai and Stølen. ${ }^{[35]}$

Figure 1 is a visualization of the $\mathrm{Cr}$-containing part of the model the authors use to describe the cation nonstoichiometry of lanthanum chromite. The parameters of the compound energy formalism are the Gibbs energies of the not necessarily neutral 12 end-member compounds ${ }^{\circ} G_{i: j: k}$, with the $8 \mathrm{Cr}$-containing compounds being the corners of the cube. Only compounds inside the neutral plane can exist on their own. 
Table 3 Model descriptions and Gibbs energy functions (a)

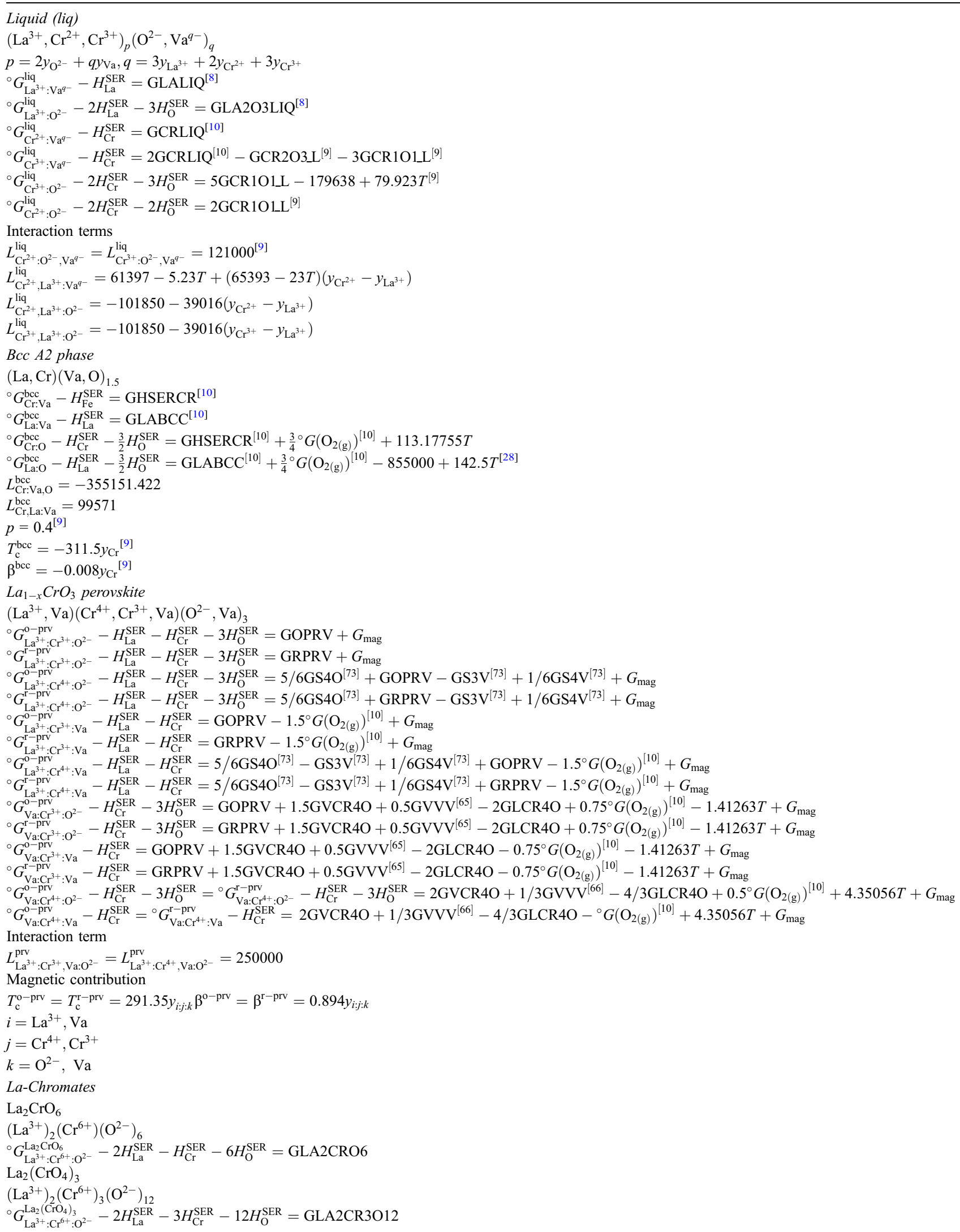




\section{Table 3 continued}

\section{Functions}

Perovskite

Stoichiometric orthorhombic perovskite

$\mathrm{GOPRV}=0.5 \mathrm{GLA} 2 \mathrm{O} 3 \mathrm{~A}^{[8]}+0.5 \mathrm{GCR} 2 \mathrm{O} 3^{[9]}-73931+3.01 T-0.68 T \ln T$

Stoichiometric rhombohedral perovskite

$\mathrm{GRPRV}=0.5 G \mathrm{LA} 2 \mathrm{O} 3 \mathrm{~A}^{[8]}+0.5 \mathrm{GCR}^{[\mathrm{O}} 3^{[9]}-73591+2.38 T-0.68 T \ln T$

Neutral nonstoichiometric perovskite endmembers

$\mathrm{GS} 4 \mathrm{O}^{[72]}=-597648+213.38 T-47.56 T \ln (T)-0.00307 T^{2}+190000 T^{-1}+0.5 \mathrm{GCR} 2 \mathrm{O} 3^{[9]}+0.25^{\circ} G\left(\mathrm{O}_{2(\mathrm{~g})}\right)^{[10]}$

$\mathrm{GS} 3 \mathrm{O}^{[72]}=-472704+191.7186 T-47.56 T \ln (T)-0.00307 T^{2}+190000 T^{-1}+0.5 \mathrm{GCR} 2 \mathrm{O} 3^{[9]}$

$\mathrm{GVCR} 4 \mathrm{O}=0.5 \mathrm{GCR}^{2} \mathrm{O}^{[9]}+0.25^{\circ} \mathrm{G}\left(\mathrm{O}_{2(\mathrm{~g})}\right)^{[10]}-291802-250 T$

$\mathrm{GLCR} 4 \mathrm{O}=1 / 3 \mathrm{GLA} 2 \mathrm{O} 3 \mathrm{~A}^{[8]}+0.5 \mathrm{GCR}^{[\mathrm{O}} 3^{[9]}+0.25^{\circ} \mathrm{G}\left(\mathrm{O}_{2(\mathrm{~g})}\right)^{[10]}-200000$

Perovskite reference ${ }^{[73]}$

$\mathrm{GS}_{4} \mathrm{~V}^{[72]}=-607870+268.9 T-47.56 T \ln (T)-0.00307 T^{2}+190000 T^{-1}+0.5 \mathrm{GCR} 2 \mathrm{O} 3-1.25^{\circ} G\left(\mathrm{O}_{2(\mathrm{~g})}\right)^{[10]}$

$\mathrm{La}_{2} \mathrm{CrO}_{6}$

$\mathrm{GLA} 2 \mathrm{CRO} 6=\mathrm{GLA} 2 \mathrm{O} 3 \mathrm{~A}^{[8]}+0.5 \mathrm{GCR}^{[\mathrm{O}} 3^{[9]}+0.75^{\circ} \mathrm{G}\left(\mathrm{O}_{2(\mathrm{~g})}\right)^{[10]}-72615-4.5 T$

$\mathrm{La}_{2}\left(\mathrm{CrO}_{4}\right)_{3}$

$\mathrm{GLA} 2 \mathrm{CR} 3 \mathrm{O} 12=\mathrm{GLA}_{2} \mathrm{O} 3 \mathrm{~A}^{[8]}+1.5 \mathrm{GCR} 2 \mathrm{O} 3^{[9]}+2.25^{\circ} \mathrm{G}\left(\mathrm{O}_{2(\mathrm{~g})}\right)^{[10]}-371557+205 T$

(a) All parameters are in SI units: $\mathrm{J}$, mol, K. $R=8.31451 \mathrm{~J} \mathrm{~mol}^{-1} \mathrm{~K}^{-1}$

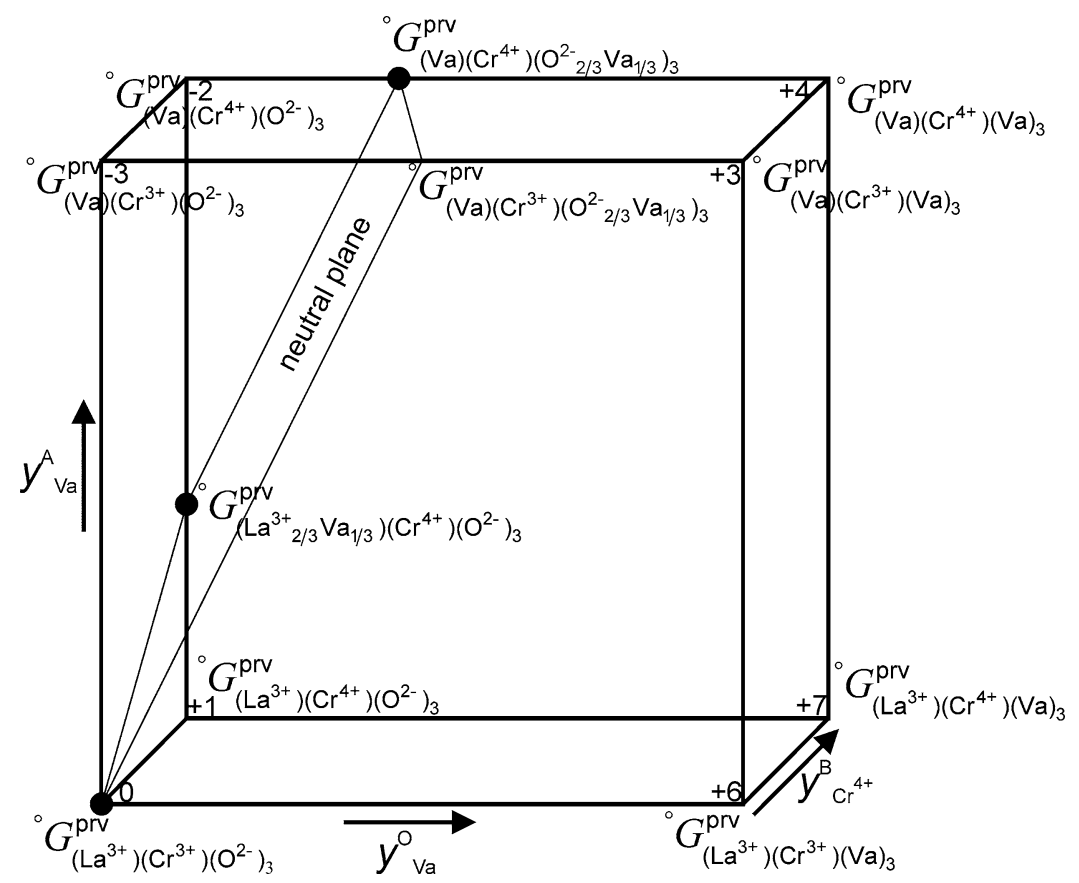

Fig. 1 Representation of the Cr-containing part of the model for nonstoichiometric lanthanum chromite. The thin lines margin the neutral plane. The neutral compounds used for the optimization are marked by the black spots

${ }^{\circ} G_{\left(\mathrm{La}^{3+}\right)\left(\mathrm{Cr}^{4+}\right)\left(\mathrm{O}^{2-}\right)_{3}}^{\mathrm{rrv}}$ and ${ }^{\circ} G_{\left(\mathrm{La}^{3+}\right)\left(\mathrm{Cr}^{4+}\right)(\mathrm{Va})_{3}}^{\mathrm{prv}}$ are given in Table 3. These endmembers of nonstoichiometric perovskite have been fixed firmly by a sufficient number of consistent experiments in the $\mathrm{LaO}_{1.5}-\mathrm{SrO}-\mathrm{CrO}_{1.5}$ system. ${ }^{[73]}$ Thus the authors adopted ${ }^{\circ} G_{\left(\mathrm{La}^{3+}\right)\left(\mathrm{Cr}^{4+}\right)\left(\mathrm{O}^{2-}\right)_{3}}^{\text {and }}{ }^{\circ} G_{\left(\mathrm{La}^{3+}\right)\left(\mathrm{Cr}^{4+}\right)(\mathrm{Va})_{3}}^{\mathrm{prv}}$ from Povoden. ${ }^{[73]}$ The neutral $\mathrm{Cr}^{4+}$-containing endmembers

$$
\begin{aligned}
& { }^{\circ} G_{\mathrm{VaCrO}{ }_{2}}^{\mathrm{prv}}-H_{\mathrm{Cr}}^{\mathrm{SER}}-2 H_{\mathrm{O}}^{\mathrm{SER}} \\
& =\frac{2}{3}{ }^{\circ} G_{\mathrm{Va}: \mathrm{Cr}^{4+}: \mathrm{O}^{2-}}+\frac{1}{3}{ }^{\circ} G_{\mathrm{Va}: \mathrm{Cr}^{4+}: \mathrm{Va}}+3 R T\left(\frac{2}{3} \ln \frac{2}{3}+\frac{1}{3} \ln \frac{1}{3}\right) \\
& =\mathrm{GVCR} 4 \mathrm{O}=\frac{1}{2}{ }^{\circ} G_{\mathrm{Cr}_{2} \mathrm{O}_{3}}^{[9]}+\frac{1}{4}{ }^{\circ} G_{\mathrm{O}_{2}}^{\mathrm{gas}[10]}+G_{\mathrm{mag}}+A+B T
\end{aligned}
$$

$(\operatorname{Eq} 7)$ 
and

$$
\begin{aligned}
& { }^{\circ} G_{\mathrm{La}_{2} / 3}^{\mathrm{prv} \mathrm{CrO}_{3}}-\frac{2}{3} H_{\mathrm{La}}^{\mathrm{SER}}-H_{\mathrm{Cr}}^{\mathrm{SER}}-3 H_{\mathrm{O}}^{\mathrm{SER}} \\
& =\frac{2}{3}^{\circ} G_{\mathrm{La}^{3+}: \mathrm{Cr}^{4+}: \mathrm{O}^{2-}}+\frac{1}{3}{ }^{\circ} G_{\mathrm{Va}^{\mathrm{Cr}}{ }^{4+}: \mathrm{O}^{2-}}+R T\left(\frac{2}{3} \ln \frac{2}{3}+\frac{1}{3} \ln \frac{1}{3}\right) \\
& =\mathrm{GLCR} 4 \mathrm{O}=\frac{1}{2}{ }^{\circ} G_{\mathrm{Cr}_{2} \mathrm{O}_{3}}^{[9]}+\frac{1}{3}{ }^{\circ} G_{\mathrm{La}_{2} \mathrm{O}_{3}}^{[8]}+\frac{1}{4}{ }^{\circ} G_{\mathrm{O}_{2}}^{\mathrm{gas}[10]}+G_{\mathrm{mag}}+A
\end{aligned}
$$

and reciprocal relations which were set zero in analogy to Grundy et al. ${ }^{[66]}$ were used to obtain ${ }^{\circ} G_{(\mathrm{Va})\left(\mathrm{Cr}^{3+}\right)\left(\mathrm{O}^{2-}\right)_{3} \text {, }}^{\mathrm{prv}}$

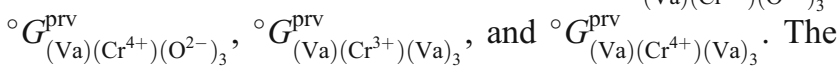
configurational entropy-term in $\mathrm{Eq} 7$ describes random mixing of $\mathrm{O}^{2-}$ with $\mathrm{Va}$ on the anion sublattice. In $\mathrm{Eq} 8$ it describes random mixing of $\mathrm{La}^{3+}$ and $\mathrm{Va}$ on the A-site.

The parameters $A$ and $B$ of Eq 7 and $A$ of Eq 8 are optimized using experimental data of excess $\mathrm{Cr}$ in perovskite. ${ }^{[56]}$ Furthermore the temperature dependence of lanthanum vacancy and hole concentrations from Akashi et al. ${ }^{[59]}$ was considered in the optimization. As cation diffusion in $\mathrm{La}_{1-x} \mathrm{CrO}_{3}$ is extremely slow even at high temperatures, the Cr-overstoichiometry in a furnace-cooled specimen reported by Khattak and $\mathrm{Cox}^{[55]}$ does most likely not represent the overstoichiometry at an intermediate temperature and was not used for the optimization.

${ }^{\circ} G_{\left(\mathrm{La}^{3+}\right)\left(\mathrm{Cr}^{3+}\right)(\mathrm{Va})_{3}}$ results from a reciprocal relation which was set zero in analogy to Grundy et al. ${ }^{[66]}$ :

$$
\begin{aligned}
& { }^{\circ} G_{\mathrm{LaCrVa}_{3}}^{\mathrm{o}-\mathrm{prv}, \mathrm{r}-\mathrm{prv}}-H_{\mathrm{La}}^{\mathrm{SER}}-H_{\mathrm{Cr}}^{\mathrm{SER}} \\
& \quad={ }^{\circ} G_{\mathrm{La}^{3+}: \mathrm{Cr}^{3+}: \mathrm{Va}}=G_{\mathrm{LaCrO}_{3}}^{\mathrm{o}-\mathrm{prv}, \mathrm{r}-\text { prv }}-\frac{3}{2}{ }^{\circ} G\left(\mathrm{O}_{2(\mathrm{~g})}\right)^{[10]}
\end{aligned}
$$

Using Eq 5 to 8 and adopting the Gibbs energies of the remaining endmembers ${ }^{\circ} G_{\left(\mathrm{La}^{3+}\right)(\mathrm{Va})\left(\mathrm{O}^{2-}\right)_{3}}^{\text {prv }},{ }^{\circ} G_{\left(\mathrm{La}^{3+}\right)(\mathrm{Va})(\mathrm{Va})_{3}}^{\mathrm{prv}}$, ${ }^{\circ} G_{(\mathrm{Va})(\mathrm{Va})\left(\mathrm{O}^{2-}\right)_{3}}^{\mathrm{prv}}$, and ${ }^{\circ} G_{(\mathrm{Va})(\mathrm{Va})(\mathrm{Va})_{3}}^{\mathrm{prv}}$ from Grundy et al., ${ }^{[66]}$ the 12 endmembers of the compound energy formalism of the perovskite phase are defined. The introduction of positive interaction parameters ${ }^{0} \mathrm{~L}_{\mathrm{La}^{3+}, \mathrm{Va}^{\mathrm{prv}} \mathrm{Cr}^{3+}: \mathrm{O}^{2-}}$ and ${ }^{0} \mathrm{~L}_{\mathrm{La}^{3+}, \mathrm{Va}^{\mathrm{prv}} \mathrm{Cr}^{4+}: \mathrm{O}^{2-}}$ that were given the same values circumvents too high $\mathrm{Cr}^{4+}$ contents at low temperatures that would be in conflict with the experiments.

\subsection{The Liquid Phase}

The two-sublattice model for ionic liquids ${ }^{[74,75]}$ was used for the description of the liquid phase of the La-Cr-O system. It was based on the liquid descriptions of the binary subsystems. The chromium species considered in the liquid are $\mathrm{Cr}^{2+}$ and $\mathrm{Cr}^{3+}$. Higher oxidation states are unlikely to exist in the liquid at normal oxygen partial pressures. The liquid is thus given by the model description $\left(\mathrm{La}^{3+}, \mathrm{Cr}^{2+}, \mathrm{Cr}^{3+}\right)_{p}\left(\mathrm{O}^{2-}, \mathrm{Va}^{q-}\right)_{q}$. The experimentally determined temperatures and liquid compositions ${ }^{[13,14]}$ at the eutectic and monotectic in the metallic $\mathrm{La}-\mathrm{Cr}$ system and the partial enthalpy of mixing of $\mathrm{Cr}, \Delta \bar{H}_{\mathrm{Cr}}{ }^{[15]}$ in La-Cr liquid were used to optimize the temperature-dependent regular
${ }^{0} L_{\mathrm{Cr}^{2+}, \mathrm{La}^{3+}: \mathrm{Va}}^{\mathrm{liq}}$ and subregular ${ }^{1} L_{\mathrm{Cr}^{2+}, \mathrm{La}^{3+}: \mathrm{Va}}^{\mathrm{liq}}$ interaction parameters to account for interactions between $\mathrm{La}$ and $\mathrm{Cr}$. Furthermore the two regular interaction parameters ${ }^{0} \mathrm{~L}_{\mathrm{Cr}^{3+}, \mathrm{La}^{3+}: \mathrm{O}^{2-}}^{\mathrm{liq}}=$ ${ }^{0} L_{\mathrm{Cr}^{2+}, \mathrm{La}^{3+}: \mathrm{O}^{2-}}^{\mathrm{liq}}$ and the two subregular ${ }^{1} L_{\mathrm{Cr}^{3+}, \mathrm{La}^{3+}: \mathrm{O}^{2-}}^{\mathrm{liq}}=$ ${ }^{1} L_{\mathrm{Cr}^{2+}, \mathrm{La}^{3+}: \mathrm{O}^{2-}}^{\mathrm{liq}}$ were optimized. It was assumed that the interactions between $\mathrm{Cr}^{2+}-\mathrm{La}^{3+}$ and $\mathrm{Cr}^{3+}-\mathrm{La}^{3+}$ are of the same order of magnitude in the oxide melt, thus the two regular interaction parameters were set equal to each other, as were the two sub-regular interaction parameters. Using the following data for their optimization led to the lowest error between experiments and calculation: the composition and temperature of the eutectic at the La-rich side and the composition of the eutectic at the $\mathrm{Cr}$-rich side in the oxide $\mathrm{LaO}_{1.5}-\mathrm{CrO}_{1.5}$ system from Tresvjatskiy et al., ${ }^{[18]}$ the temperature of the eutectic at the Cr-rich side from Berjoan, ${ }^{[19]}$ and the congruent melting temperature of the perovskite phase from Coutures et al ${ }^{[20]}$ and Foëx. $^{[21]}$ Berjoan ${ }^{[32]}$ and Tresvjatskiy et al. ${ }^{[18]}$ did not specify the value of the prevailing oxygen partial pressure during their phase diagram experiments conducted in an argon atmosphere. As a value of the oxygen partial pressure is required for the optimization, we defined $p_{\mathrm{O}_{2}}=1 \mathrm{~Pa}$.

\section{Results and Discussion}

\subsection{The La-Cr System}

The calculated phase diagram of the La-Cr system is presented in Fig. 2, together with experimental phase diagram data. ${ }^{[12-P 4,17]}$. The positive value of ${ }^{0} L_{\mathrm{Cr} \text {.La:Va }}^{\mathrm{bcc}}$ used to model the bcc phase results in a large miscibility gap between the La-rich and Cr-rich metals, which is tantamount to a small solubility of $\mathrm{La}$ in $\alpha \mathrm{Cr}_{\mathrm{ss}}$ in agreement with the experiments. ${ }^{[14,17]}$ The model description of the bcc phase results in a tiny solubility of $\mathrm{Cr}$ in $\mathrm{La}(\mathrm{bcc})$, denoted as $\gamma \mathrm{La}_{\mathrm{ss}}$, of $2 \times 10^{-3}$ at.\% at $1134 \mathrm{~K}$, the lowest temperature of stable $\gamma \mathrm{La}_{\mathrm{ss}}$, which further decreases as a function of increasing temperature. The calculated enthalpies of mixing are shown in Fig. 3 together with the experimentally determined value $e^{[15]}$ that is well reproduced by the calculation. Considerable deviations of the calculated liquidus from experiments at the Cr-rich side of the system can be ascribed to the problem of two different melting temperatures for $\mathrm{Cr}$ cited in the literature, which are 2180 and $2130 \mathrm{~K}$. The higher value was favored by Dinsdale ${ }^{[10]}$ and is adopted in this study, whereas the lower melting temperature was chosen by Savitskii et al. ${ }^{[12]}$ and Svechnikov et al. ${ }^{[14]}$

A satisfying reproduction of the experimental data was obtained by considering a moderate temperature dependence of ${ }^{0} L_{\mathrm{Cr}^{2+}, \mathrm{La}^{3+}: \mathrm{Va}}^{\text {liq }}$ and ${ }^{1} L_{\mathrm{Cr}^{2+}, \mathrm{La}^{3+}: \mathrm{Va}}^{\text {liq }}$. This is unfortunately associated with an inverse liquid-liquid miscibility gap with a minimum at $x(\mathrm{Cr})=0.25$ and $T \approx 5000 \mathrm{~K}$ that is of course unphysical. 


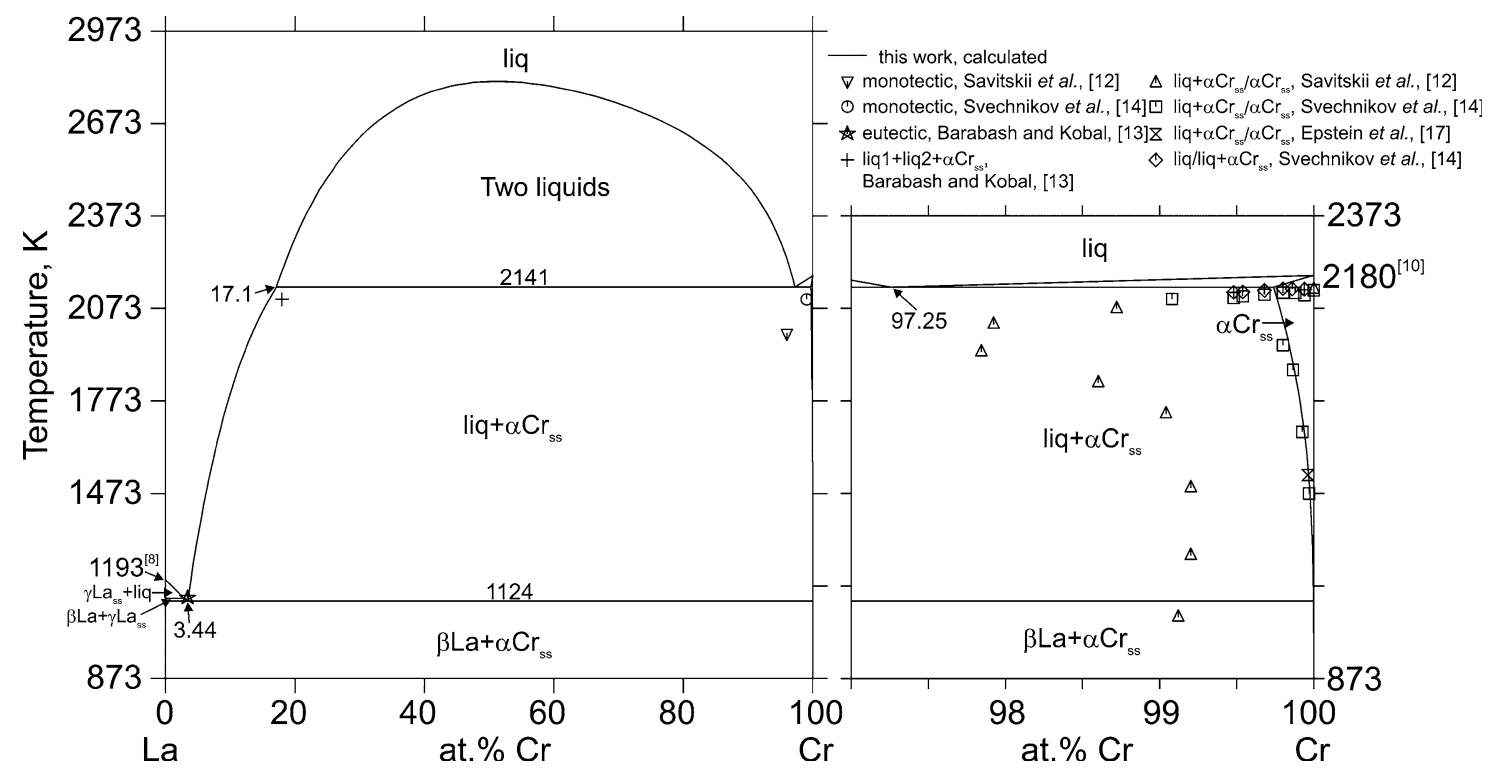

Fig. 2 Calculated phase diagram of the La-Cr system with data from the literature included (symbols)

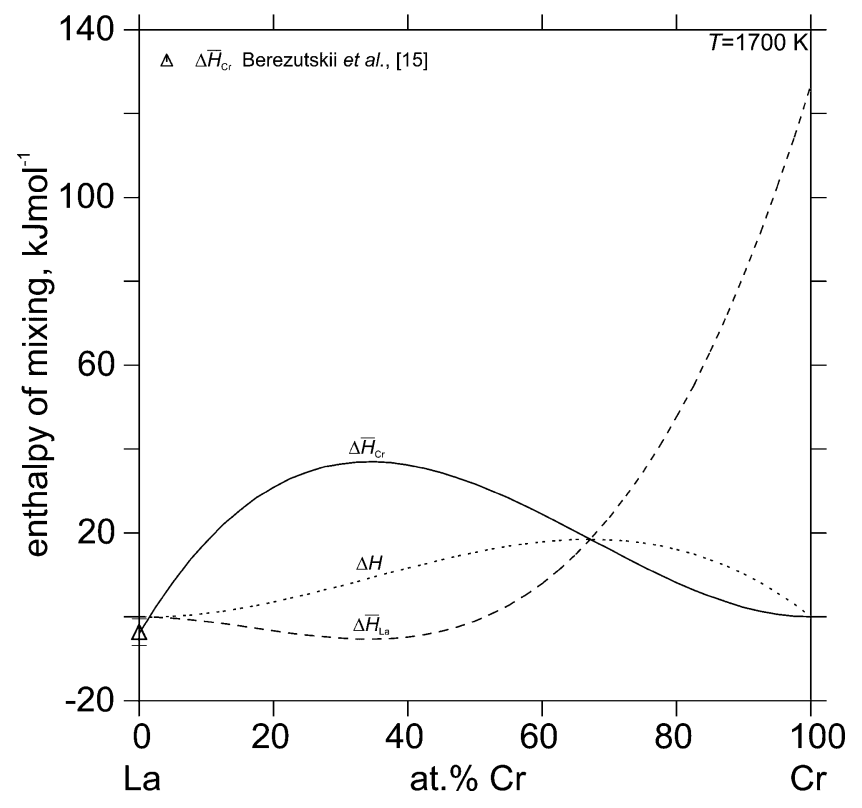

Fig. 3 Calculated partial enthalpies of mixing of $\mathrm{La}$ and $\mathrm{Cr}$ in La-Cr liquid, and integral enthalpies of mixing as a function of composition, with the experiment from Berezutskii et al. ${ }^{[15]}$ at $1700 \mathrm{~K}$ included (symbol with error-bar)

\subsection{The La-Cr-O System}

5.2.1 Phase Equilibria. Calculated $\mathrm{LaO}_{1.5}-\mathrm{CrO}_{1.5}$ phase diagrams in pure oxygen at $p_{\mathrm{O}_{2}}=10^{5} \mathrm{~Pa}$, in air at $p_{\mathrm{O}_{2}}=$ $21,278 \mathrm{~Pa}$, and under reducing conditions at $p_{\mathrm{O}_{2}}=1 \mathrm{~Pa}$ representing the typical oxygen partial pressure in argon atmosphere are shown in Fig. 4 together with experimental data. ${ }^{[18-21]}$
Excess $\mathrm{Cr}$ in lanthanum chromite is favored at high oxygen partial pressures. A decrease of $\mathrm{Cr}^{4+}$ during annealing of an originally lanthanum-deficient perovskite phase under reducing conditions is predicted by the model, reflected by the disappearance of $\mathrm{Cr}$ overstoichiometry. This is in line with the interpretations of Raman spectra from Iliev et al ${ }^{[56]} \mathrm{Be}$ it that the reported thermodynamic data of $\mathrm{La}_{2} \mathrm{CrO}_{6}{ }^{[19]}$ and $\mathrm{La}_{2}\left(\mathrm{CrO}_{4}\right)_{3}{ }^{[30]}$ are correct, lanthanum chromite is expected to be metastable at room temperature, and orthorhombic perovskite is stable only at $p_{\mathrm{O}_{2}} \leq 10^{2} \mathrm{~Pa}$. $\mathrm{La}_{2} \mathrm{CrO}_{6}$ is stable within a wide temperature-range in pure oxygen, whereas it does not form in air and argon atmosphere.

Due to the ambiguous oxygen partial pressure of phase diagram experiments ${ }^{[18,19]}$ and the conflicting data on the melting temperature of lanthanum chromite in argon atmosphere $^{[18]}$ the presented liquid description is rather tentative. Under oxidizing conditions $\mathrm{Cr}^{3+}$ is favored over $\mathrm{Cr}^{2+}$ in the liquid. Analogous to $\mathrm{Fe}$ in the $\mathrm{La}-\mathrm{Fe}-\mathrm{O}$ system ${ }^{[63]}$ this oxidation of $\mathrm{Cr}^{2+}$ to $\mathrm{Cr}^{3+}$ governs shifts of eutectic compositions and temperatures and the increase of the melting temperature of the perovskite phase on increasing the oxygen partial pressure. On the other hand a significant amount of $\mathrm{Cr}^{3+}$ in the ionic liquid is reduced to $\mathrm{Cr}^{2+}$ under reducing conditions, and the liquid stability increases considerably at the Cr-rich part of the system leading to a considerably lowered eutectic temperature. The liquid description using the two-sublattice model for ionic liquids also resulted in a significantly larger decrease of the melting temperature of lanthanum chromite at $p_{\mathrm{O}_{2}} \approx 1 \mathrm{~Pa}$ than the given values in argon atmosphere. ${ }^{[18]}$ Despite this discrepancy we did not go for an alternative liquid model for the sake of consistency with our previously assessed systems.

In Fig. 5 calculated phase equilibria of the $\mathrm{La}-\mathrm{Cr}-\mathrm{O}$ system at $1273 \mathrm{~K}$ are shown as a function of oxygen partial pressure. It is obvious that no mutual solubilities of $\mathrm{La}$ and 


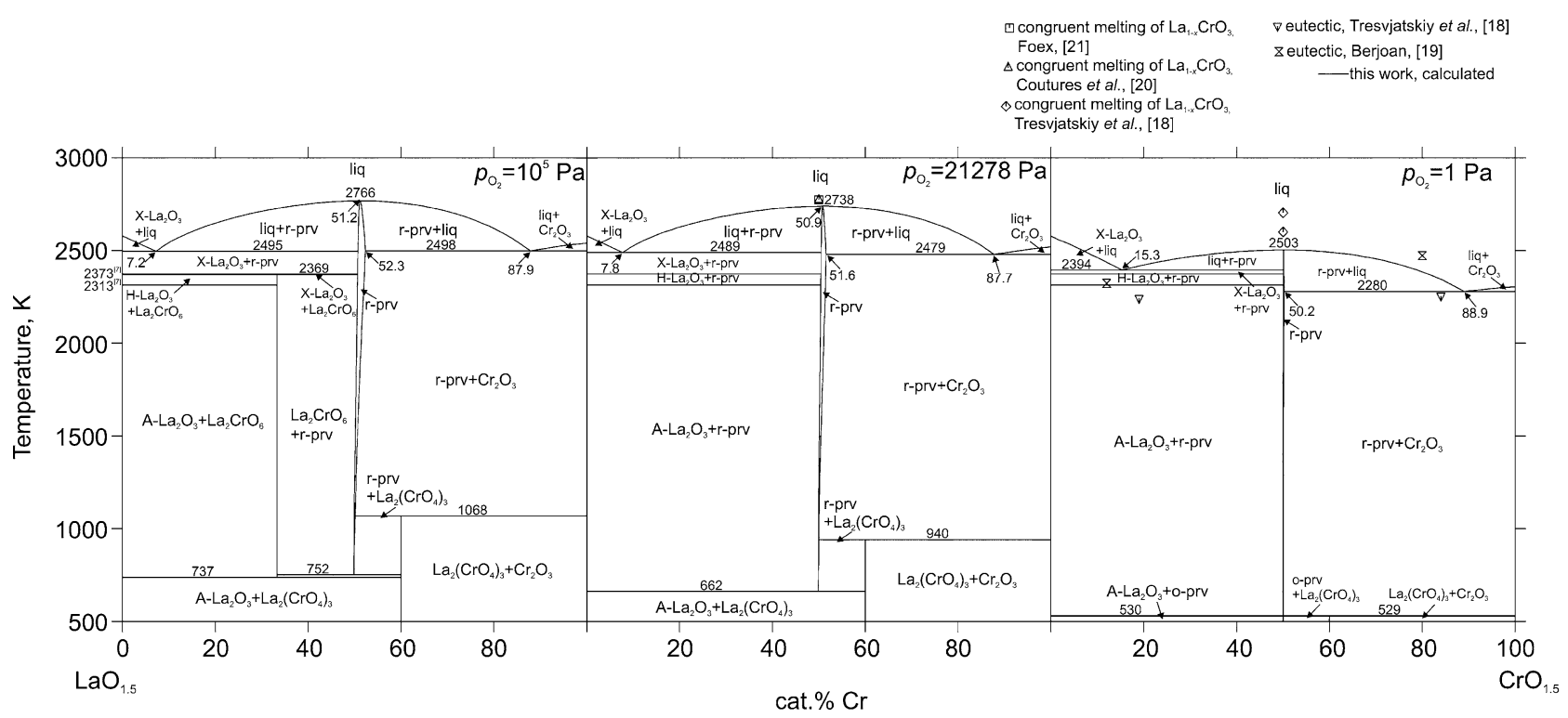

Fig. 4 Calculated phase diagrams of the $\mathrm{LaO}_{1.5}-\mathrm{CrO}_{1.5}$ system in pure oxygen, air atmosphere, and under reducing conditions representing argon atmosphere at $p_{\mathrm{O}_{2}}=1 \mathrm{~Pa}$ with experimental data included (symbols)

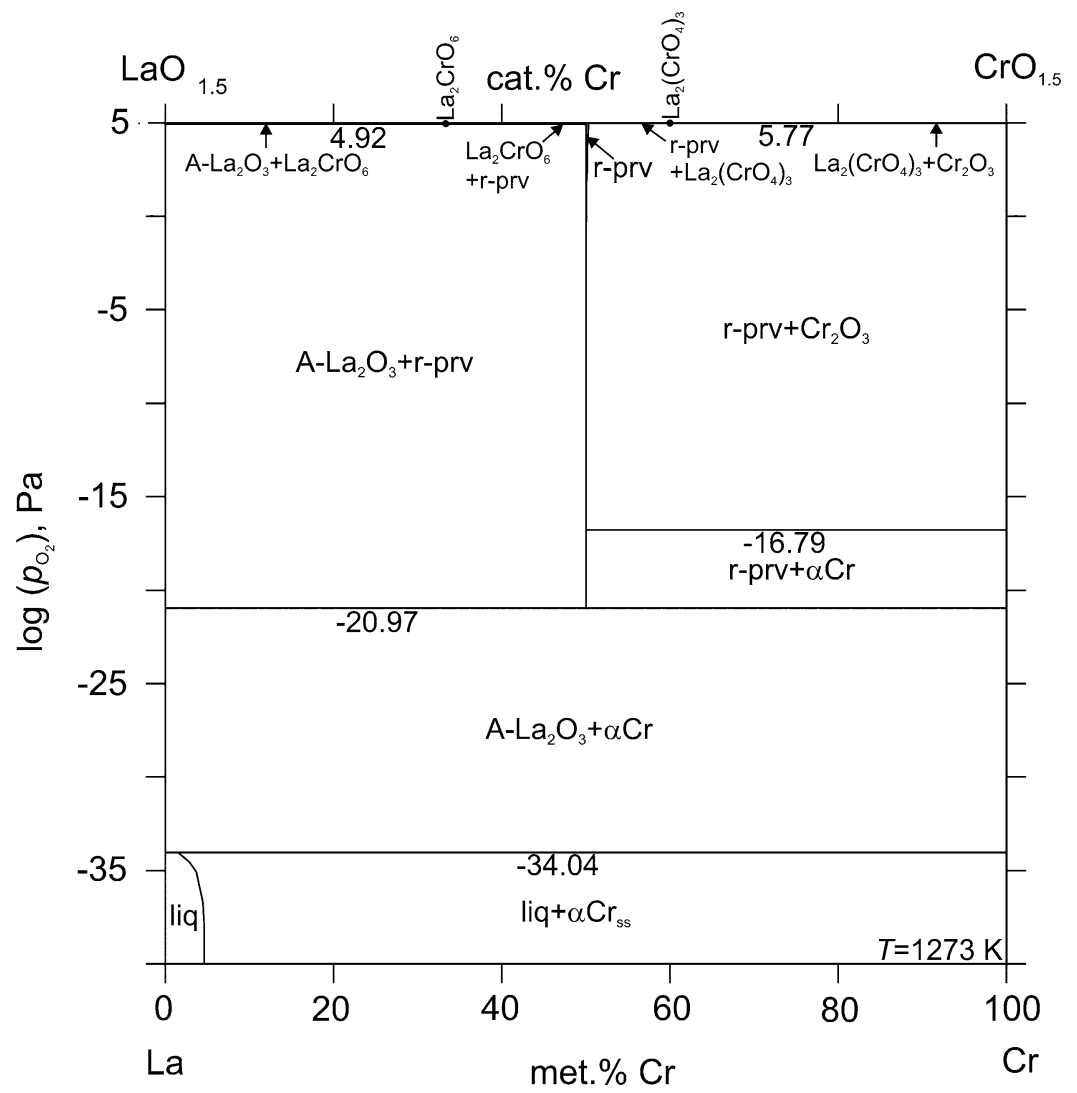

Fig. 5 Calculated phase equilibria of the La-Cr-O system at $T=1273 \mathrm{~K}$ as a function of oxygen partial pressure

$\mathrm{Cr}$ in bec metal in equilibrium with oxides are expected. The same oxygen solubility in $\mathrm{Cr}$ as in the assessment by Povoden et al. ${ }^{[9]}$ was obtained using the new model description $(\mathrm{Cr})(\mathrm{O}, \mathrm{Va})_{1.5}$. At $p_{\mathrm{O}_{2}}=10^{-34.04} \mathrm{~Pa}$ metallic liquid forms at the lanthanum-rich side of the phase diagram. 
5.2.2 Thermodynamic Data. Calculated thermodynamic data of solid oxides are listed together with experimental data from the literature in Table 1. Calculated and experimental data on the orthorhombic to rhombohedral transition of $\mathrm{LaCrO}_{3}$ are listed in Table 2. Table 3 is a compilation of the Gibbs energy functions and model descriptions of the phases in the La-Cr-O system obtained in this study.

5.2.3 Lanthanum Chromates. Testing an optimization of model parameters of $\mathrm{La}_{2}\left(\mathrm{CrO}_{4}\right)_{3}$ by using all available thermodynamic data ${ }^{[29,31]}$ resulted in gross disagreement between optimized and reported values. The considerable error might be explained by experimental difficulties to reach equilibrium at the low investigation temperatures, and/ or by significant deviations between the thermodynamic standard data used for the calculation of the enthalpy of formation from the elements ${ }^{[29]}$ and assessed values. ${ }^{[8-10]}$ Anyway the model parameters were fitted to the experimental data, ${ }^{[30]}$ whereas the calculated standard enthalpy of formation from the elements ${ }^{[29]}$ was rejected, bearing in mind the high degree of uncertainty of the resulting description. The perovskite phase: the calculated heat capacities of $\mathrm{LaCrO}_{3}$ are compared with experiments from the literature in Fig. 6 . The calculated $C_{p}$-curve extrapolates well to high temperatures. The use of $C_{p}$-data from Sakai and Stølen ${ }^{[35]}$ along with enthalpy increment-data from Suponitskii $^{[30]}$ to optimize the parameter $C T \ln T$ of the Gibbs energy of stoichiometric perovskite resulted in the lowest error between experiments and calculation. As $C T \ln T$ was set equal for o-prv and r-prv, their $C_{p}$ is the same. The experimentally determined $C_{p}$-peak around $545 \mathrm{~K}$ caused by the first-order transition o-prv $\leftrightarrow$ r-prv is in fact a discontinuity which cannot be implemented in the model. The calculated transition temperature of $540 \mathrm{~K}$ is shown by the broken line in Fig. 6 . The calculated $C_{p}$-peak at $290 \mathrm{~K}$ reflects the temperature of the magnetic orderdisorder transition, the transition temperature being in agreement with the experiments. Two values for the magnetic parameter $p$ are possible depending on the crystal structure, $p=0.28$ and $p=0.4$, whereby the proper $p$-value for structures other than bcc, fcc, and hcp is not available in the literature. The $C_{p}$-anomaly is equally well reproduced by the model ${ }^{[70,71]}$ using $p=0.28$ or $p=0.4$. For the sake of compatibility with the recent assessment of the La-Fe-O system $^{[63]}$ we chose $p=0.28$. Experimental enthalpy increments $^{[30]}$ are well reproduced by the calculation (see Table 1). Due to the consistency between both groups of calorimetric experiments ${ }^{[30,35]}$ the term $C T \ln T$ is fixed firmly. A small peak which was found around $855 \mathrm{~K}$ can be explained most likely by the decomposition of an undetected impurity phase. ${ }^{[35]}$

The calculated Gibbs energies of the formation of $\mathrm{LaCrO}_{3}$ from the oxides

$\frac{1}{2} \mathrm{La}_{2} \mathrm{O}_{3}+\frac{1}{2} \mathrm{Cr}_{2} \mathrm{O}_{3} \rightarrow \mathrm{LaCrO}_{3}$

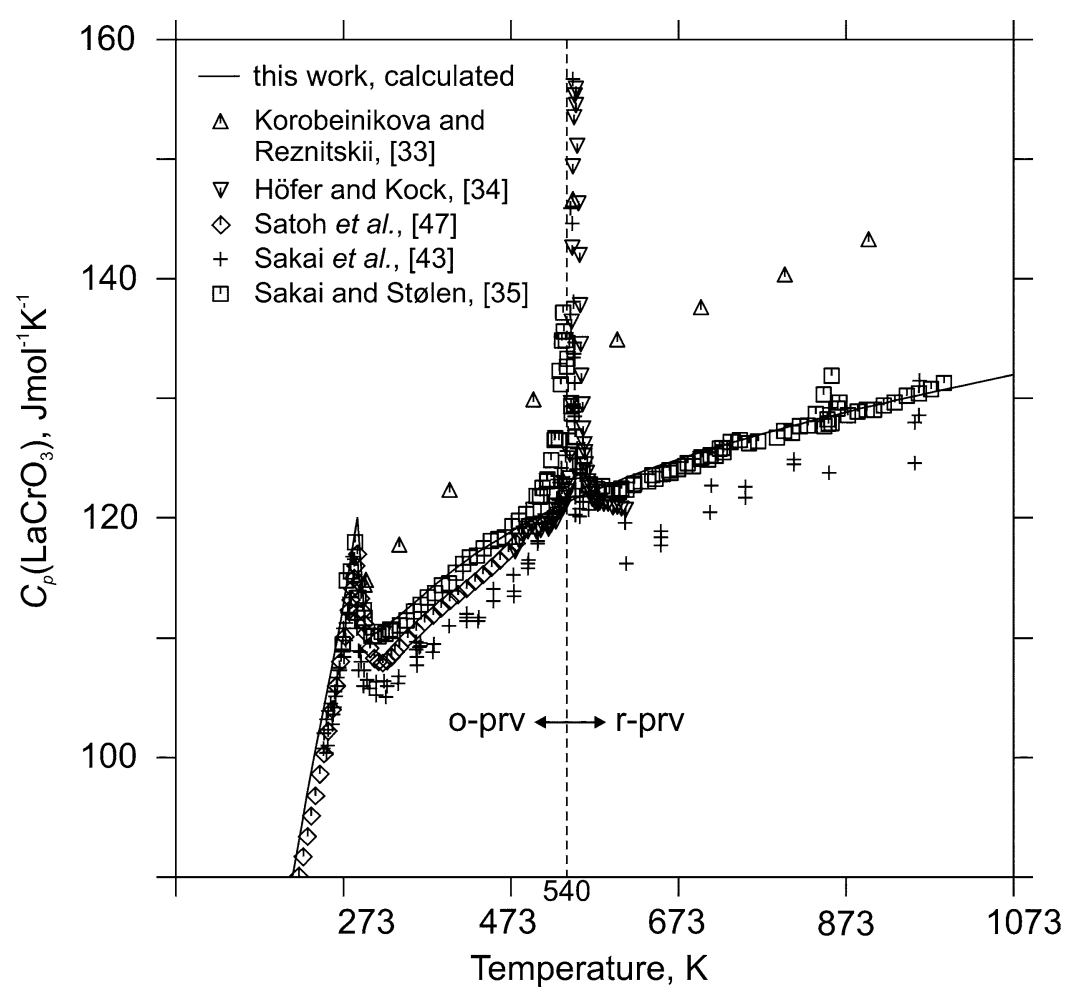

Fig. 6 Calculated heat capacities of $\mathrm{LaCrO}_{3}$ as a function of $T$ with experimental data included (symbols). The dashed line marks the temperature of the o-prv $\leftrightarrow$ r-prv transition 
are listed as a function of temperature together with data from the literature ${ }^{[49-53]}$ in Table 1. The resulting Gibbs energies of formation from emf-measurements are remarkably less negative than the Gibbs energies of formation derived from Knudsen mass spectrometry. ${ }^{[53]}$ Only the use of the latter data for the optimization resulted in the proper phase diagram with congruent melting of the perovskite phase and two eutectic. It needs to be clarified why all of the emf-measurements are problematic: Azad et al. ${ }^{[50]}$ stated that the Gibbs energy of formation of $\mathrm{LaCrO}_{3}$ cannot be studied properly using the solid oxide electrolyte method due to experimental difficulties in measuring the low oxygen potentials encountered in a mixture of coexisting $\mathrm{LaCrO}_{3}-\mathrm{La}_{2} \mathrm{O}_{3}-\mathrm{Cr}$. Yet it is obvious that the $\mathrm{CaF}_{2}$-based emf-technique is neither suitable for the determination of thermodynamic data of lanthanum chromite, as it unavoidably leads to emf that are too low. A possible explanation is found in a study by Akila and Jacob: ${ }^{[76]}$ Fine precipitates of $\mathrm{CaO}$ can form on the surface of $\mathrm{CaF}_{2}$ in water- or oxygen-containing atmosphere. In this case the emf depends on the activity of $\mathrm{CaO}$ at the electrode/electrolyte interface, and changing activity of $\mathrm{CaO}$ at the electrode/electrolyte interface can alter the chemical potential of fluorine at this electrode and thus the emf across the electrolyte.

5.2.4 Chemical Stability of the Perovskite Phase. The calculated oxygen partial pressure for the decomposition of lanthanum chromite by the reaction

$\mathrm{LaCrO}_{3} \rightarrow \frac{1}{2} \mathrm{La}_{2} \mathrm{O}_{3}+\alpha \mathrm{Cr}+\frac{3}{4} \mathrm{O}_{2}(\mathrm{~g}) \uparrow$

is $p_{\mathrm{O}_{2}}=10^{-20.97}$ at $1273 \mathrm{~K}$. The calculated decomposition of the perovskite phase by Eq 11 is plotted as a function of temperature and oxygen partial pressure in Fig. 7.

5.2.5 Defect Chemistry of the Perovskite Phase. Applying a defect chemistry analysis of $\mathrm{La}_{1-x} \mathrm{CrO}_{3}$ in equilibrium with $\mathrm{Cr}_{2} \mathrm{O}_{3}$ the following defect reaction for its oxidation can be written in the sublattice form, if $\left[\mathrm{Va}_{\mathrm{Cr}}^{\prime \prime \prime}\right]$ and $\left[\mathrm{Va}_{\mathrm{O}}^{\bullet \bullet}\right]$ are assumed to be negligible according to Akashi et al.: ${ }^{[59]}$

$$
\left(\mathrm{La}^{3+}\right)\left(\mathrm{Cr}^{3+}\right)\left(\mathrm{O}^{2-}\right)_{3}+\frac{1}{4} \mathrm{O}_{2(\mathrm{~g})} \rightarrow\left(\mathrm{La}_{2 / 3}^{3+} \mathrm{Va}_{1 / 3}\right)\left(\mathrm{Cr}^{4+}\right)\left(\mathrm{O}^{2-}\right)_{3}
$$

Using Kröger-Vink notation this defect reaction reads

$\mathrm{La}_{\mathrm{La}}^{x}+\mathrm{Cr}_{\mathrm{Cr}}^{x}+3 \mathrm{O}_{\mathrm{O}}^{x}+\frac{1}{4} \mathrm{O}_{2(\mathrm{~g})} \rightarrow \frac{2}{3} \mathrm{La}_{\mathrm{La}}^{x}+\frac{1}{3} \mathrm{Va}_{\mathrm{La}}^{\prime \prime \prime}+\mathrm{Cr}_{\mathrm{Cr}}^{\bullet}+3 \mathrm{O}_{\mathrm{O}}^{x}$

and the equilibrium constant of the oxidation reaction is

$K_{o x}=\frac{\left[\mathrm{Va}_{\mathrm{La}}^{\prime \prime \prime}\right]^{1 / 3}\left[\mathrm{La}_{\mathrm{La}}^{x}\right]^{2 / 3}\left[\mathrm{Cr}_{\mathrm{Cr}}^{\bullet}\right]\left[\mathrm{O}_{\mathrm{O}}^{x}\right]^{3}}{\left[\mathrm{La}_{\mathrm{La}}^{x}\right]\left[\mathrm{Cr}_{\mathrm{Cr}}^{x}\right]\left[\mathrm{O}_{\mathrm{O}}^{x}\right]^{3} p_{\mathrm{O}_{2}}^{1 / 4}}$

For small oxidation extent $\left[\mathrm{La}_{\mathrm{La}}^{x}\right],\left[\mathrm{Cr}_{\mathrm{Cr}}^{x}\right]$, and $\left[\mathrm{O}_{\mathrm{O}}^{x}\right]$ can be considered to be $\sim 1$, and charge neutrality is maintained by

$$
\left[\mathrm{Va}_{\mathrm{La}}^{\prime \prime \prime}\right]=\frac{1}{3}\left[\mathrm{Cr}_{\mathrm{Cr}}^{\bullet}\right]
$$

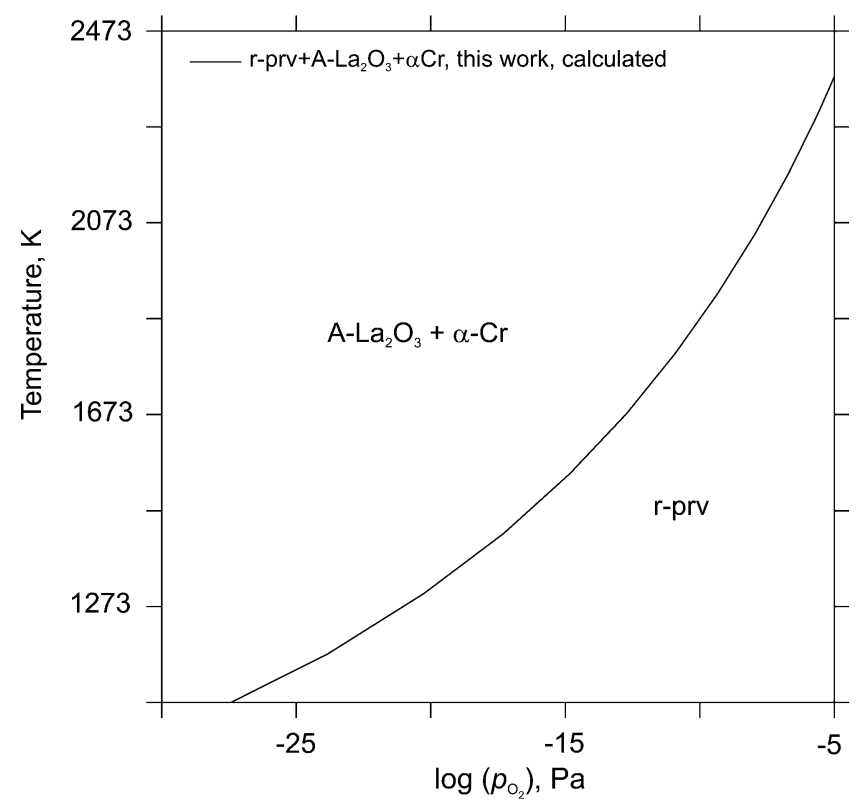

Fig. 7 Calculated decomposition of lanthanum chromite as a function of temperature and oxygen partial pressure

Substituting this into Eq 14 gives the proportionalities $\left[\mathrm{Va}_{\mathrm{La}}^{\prime \prime \prime}\right],\left[\mathrm{Cr}_{\mathrm{Cr}}^{\bullet}\right] \propto p_{\mathrm{O}_{2}}^{3 / 16}$.

The concentrations of the defects $\mathrm{La}_{\mathrm{La}}^{x}, \mathrm{Va}_{\mathrm{La}}^{\prime \prime \prime}, \mathrm{Cr}_{\mathrm{Cr}}^{x}$, and $\mathrm{Cr}_{\mathrm{Cr}}^{\bullet}$ in $\mathrm{La}_{1-x} \mathrm{CrO}_{3}$ correspond to the site fractions $y_{\mathrm{A}_{\mathrm{La}^{3+}}}^{\mathrm{prv}}, y_{\mathrm{A} \mathrm{Va}}^{\mathrm{pr}}, y_{\mathrm{B}^{2} \mathrm{Cr}^{3+}}^{\text {prv }}$, and $y_{\mathrm{B}_{\mathrm{Cr}}{ }^{4+}}^{\text {prv }}$ in the compound energy formalism. $y_{\mathrm{A}_{\mathrm{La}^{3+}}}^{\mathrm{prv}}, y_{\mathrm{A} V \mathrm{a}}^{\mathrm{prv}}, y_{\mathrm{B}_{\mathrm{Cr}}{ }^{3+}}^{\text {prv }}, y_{\mathrm{B}_{\mathrm{Cr}}{ }^{4+}}^{\text {prv }}$ and the tiny fractions $y_{\mathrm{BVa}}^{\text {prv }}$ and $y_{\mathrm{O}}^{\mathrm{pa}}$ are plotted logarithmically as a function of $\log p_{\mathrm{O}_{2}}$ at 1073 and $1673 \mathrm{~K}$ in Fig. 8 for lanthanum chromite in equilibrium with $\mathrm{Cr}_{2} \mathrm{O}_{3}$. The line for $y_{\mathrm{A}_{\mathrm{La}}^{3+}}^{\text {prv }}$ at $1073 \mathrm{~K}$ cannot be seen as it is very close to 1 . At $1073 \mathrm{~K}$ a constant slope of 3/16 of the defect concentrations $\left[\mathrm{Va}_{\mathrm{La}}^{\prime \prime \prime}\right]$ and $\left[\mathrm{Cr}_{\mathrm{Cr}}^{\bullet}\right]$ shown in the triangle, is calculated from very high to very low oxygen partial pressures. This slope is fixed by the defect reaction $\mathrm{Eq} 12$. At $1673 \mathrm{~K}$ the slope of $3 / 16$ of $\left[\mathrm{Va}_{\mathrm{La}}^{\prime \prime \prime}\right]$ and $\left[\mathrm{Cr}_{\mathrm{Cr}}^{\bullet}\right]$ is reproduced by the calculated slope using the compound energy formalism at $10^{5}>$ $p_{\mathrm{O}_{2}}>10^{-8} \mathrm{~Pa}$; hence oxidation of $\mathrm{LaCrO}_{3}$ to $\mathrm{La}_{1-x} \mathrm{CrO}_{3}$ governs the electrical conductivity of perovskite with fixed activity of $\mathrm{Cr}_{2} \mathrm{O}_{3}$ at unity between $p_{\mathrm{O}_{2}}=10^{5}$ and $10^{-8} \mathrm{~Pa}$ at this temperature. The calculated slopes of $\left[\mathrm{Va}_{\mathrm{La}}^{\prime \prime \prime}\right]$ and $\left[\mathrm{Cr}_{\mathrm{Cr}}^{\bullet}\right]$ are equal to the slope of the electrical conductivity from 1573 to $1673 \mathrm{~K}$ between $p_{\mathrm{O}_{2}}=1.0 \times 10^{3} \mathrm{~Pa}$ and $p_{\mathrm{O}_{2}}=$ $2.0 \times 10^{4} \mathrm{~Pa}$ determined by Akashi et al. ${ }^{[59]}$ The conflicting data from Shvaiko-Shvaikovskii et al. ${ }^{[58]}$ may be explained by problems of reaching equilibrium due to extraordinarily slow cation diffusion in lanthanum chromite. In Fig. 9 the calculated slopes of $\mathrm{Va}_{\mathrm{La}}^{\prime \prime \prime}$ and $\mathrm{Cr}_{\mathrm{Cr}}^{\bullet}$ are compared with slopes of $\left[\mathrm{Va}_{\mathrm{La}}^{\prime \prime \prime}\right]$ and $\left[\mathrm{Cr}_{\mathrm{Cr}}^{\bullet}\right]$ determined by Akashi et al. ${ }^{[59]}$ as a function of reciprocal temperatures. The calculated concentrations agree well with the data derived from electrical conductivity measurements. ${ }^{[59]}$ The calculated 


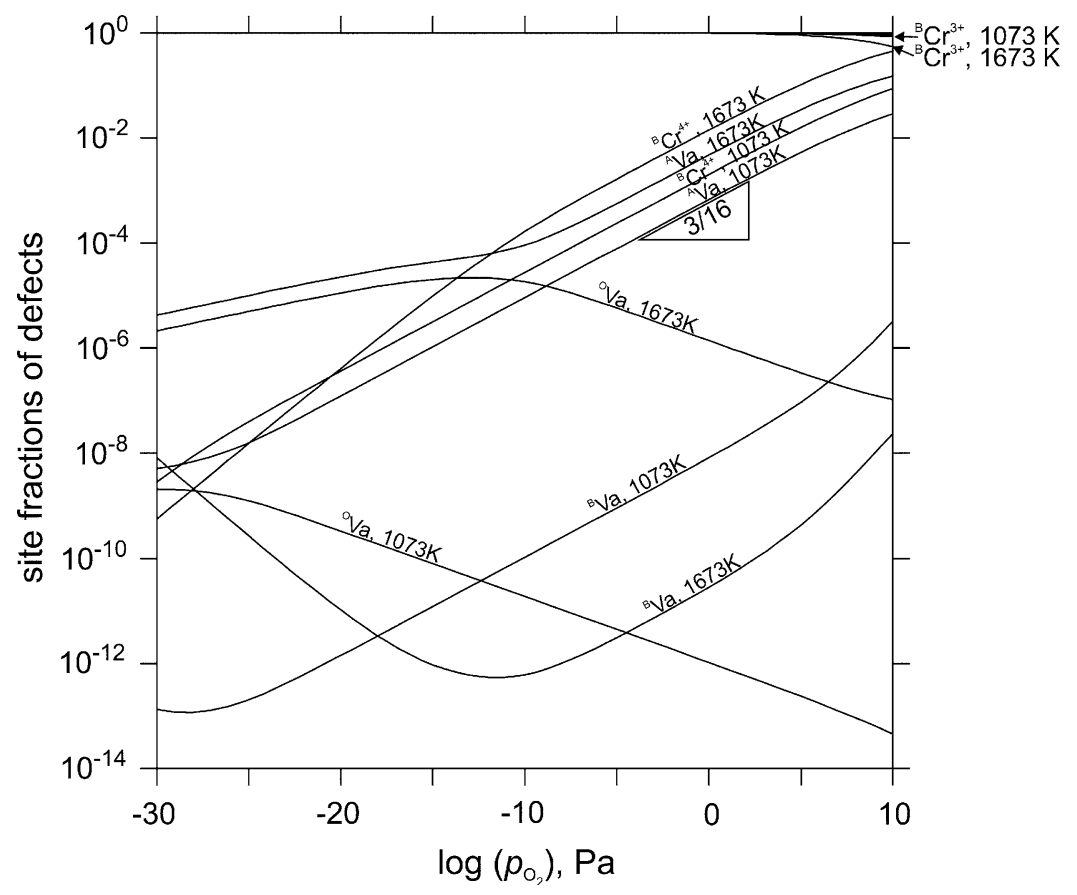

Fig. 8 Calculated site fractions of species in $\mathrm{La}_{1-x} \mathrm{CrO}_{3}$ in the thermodynamic equilibrium with $\mathrm{Cr}_{2} \mathrm{O}_{3}$ logarithmically plotted at $1073 \mathrm{~K}$ and $1673 \mathrm{~K}$ as a function of $p_{\mathrm{O}_{2}}$. The slope of $3 / 16$ of the calculated defect concentrations is indicated in the triangle

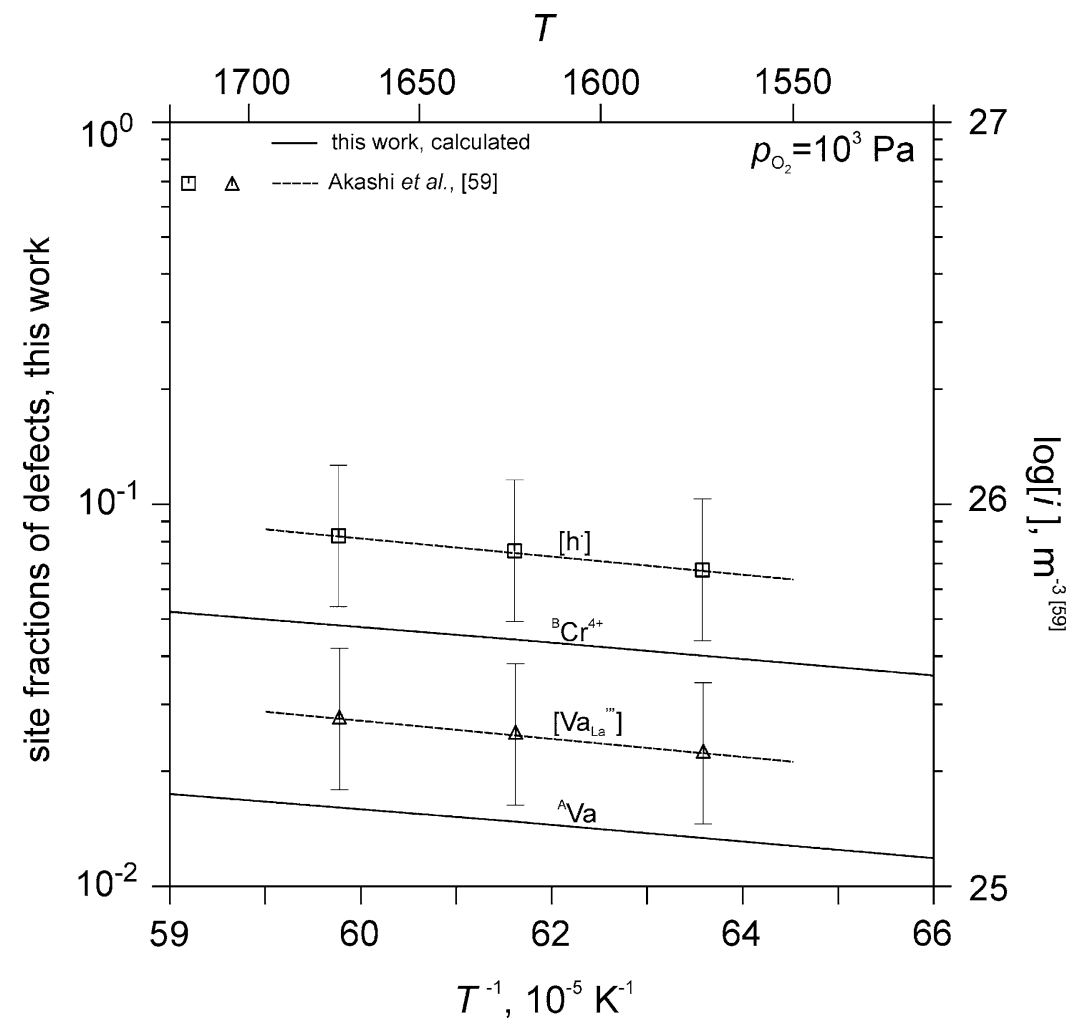

Fig. 9 Calculated defect concentrations in $\mathrm{La}_{1-x} \mathrm{CrO}_{3}$ in the thermodynamic equilibrium with $\mathrm{Cr}_{2} \mathrm{O}_{3}$ (solid lines) logarithmically plotted as a function of reciprocal temperature along with the data from Akashi et al. ${ }^{[59]}$ derived from electrical conductivity measurements (symbols with error-bars, broken lines) 
amount of $\left[\mathrm{Va}_{\mathrm{La}}^{\prime \prime \prime}\right]$ relative to $\left[\mathrm{Cr}_{\mathrm{Cr}}^{\circ}\right]$ is fixed by the criterion for charge neutrality, Eq 15, as calculated $\left[\mathrm{Va}_{\mathrm{Cr}}^{\prime \prime \prime}\right]$ and $\left[\mathrm{Va}_{\mathrm{O}}^{\bullet \bullet}\right]$ are very small. The calculated relative defect concentrations are in line with those proposed by Akashi et al. ${ }^{[59]}$

The presented defect chemistry calculations are still rather tentative, as the temperature and oxygen partial pressure dependence of excess $\mathrm{Cr}$ in $\mathrm{La}_{1-x} \mathrm{CrO}_{3}$ has not been investigated systematically so far.

\section{Conclusions}

Model parameters of the presented thermodynamic La-Cr-O database were optimized with assessed thermodynamic and phase diagram data.

The thermodynamic descriptions of lanthanum chromates and the liquid phase are rather tentative due to humble or sketchy experimental information.

The thermodynamic modeling of lanthanum chromite was based on experimental thermodynamic data reported by Peck et al. ${ }^{[53]}$ and Cheng and Navrotsky, ${ }^{[46]}$ as the use of these data for the optimization of model parameters resulted in a proper reproduction of the phase equilibria derived from experiments. The orthorhombic to rhombohedral transition in lanthanum chromite and the magnetic order-disorder transformation are well reproduced by the model.

Using the new database the stability limits of lanthanum chromite in function of temperature and oxygen partial pressure can be quantified.

The proposed existence of lanthanum vacancies and holes to maintain charge neutrality in lanthanum chromite with excess $\mathrm{Cr}$ is reproduced by the model, and the calculated slopes of defect concentrations in function of oxygen partial pressure and temperature are in line with the slopes derived from electrical conductivity measurements. However the amounts of excess $\mathrm{Cr}$ in $\mathrm{La}_{1-x} \mathrm{CrO}_{3}$ used for the optimization of the cation nonstoichiometry are preliminary, and further work on the temperature dependence of excess $\mathrm{Cr}$ as a function of temperature and oxygen partial pressure would allow a more accurate quantification of the defect chemistry of lanthanum chromite.

\section{Acknowledgments}

This work was financially supported by the Federal Agency for Education and Science, 6th Framework Program for Research and Technical Development of the European Union.

\section{References}

1. D. Das, M. Miller, H. Nickel, and K. Hilpert, First European Solid Oxide Fuel Cell Forum Proceedings, U. Bossel, Ed., Vol. 2 (Göttingen), Druckerei J. Kinzel, 1994, p 703

2. S.P.S. Badwal, R. Deller, K. Foger, Y. Ramprakash, and J.P. Zhang, Interaction Between Chromia Forming Alloy Inter- connects and Air Electrode of Solid Oxide Fuel Cells, Solid State Ionics, 1997, 99, p 297-310

3. S.P. Jiang, J.P. Zhang, and K. Foger, Deposition of Chromium Species at Sr-Doped $\mathrm{LaMnO}_{3}$ Electrodes in Solid Oxide Fuel Cells. I. Mechanism and Kinetics, J. Electrochem. Soc., 2000, 147(11), p 4013-4022

4. A. Carlsson, A.-M.H. Kjaer, and J.G. Larsen, Cr-Mn Deposition at the Three-Phase Boundary Observed by TEM, Proceedings of the 26th Risoe International Symposium on Materials Science: Solid State Electrochemistry, S. Linderoth, A. Smith et al., Eds. (Roskilde, Denmark), Risø National Laboratory, 2005, p 155-162

5. G.-Y. Lee, R.-H. Song, J.-H. Kim, D.-H. Peck, T.-H. Lim, Y.-G. Shul, and D.-R. Shin, Properties of $\mathrm{Cu}, \mathrm{Ni}$, and V Doped-LaCrO ${ }_{3}$ Interconnect Materials Prepared by Pechini, Ultrasonic Spray Pyrolysis and Glycine Nitrate Processes for SOFC, J. Electroceram., 2006, 17, p 723-727

6. M. Liu, L. Zhao, D. Dong, S. Wang, J. Diwu, X. Liu, and G. Meng, High Sintering Ability and Electrical Conductivity of $\mathrm{Zn}$ Doped $\mathrm{La}(\mathrm{Ca}) \mathrm{CrO}_{3}$ Based Interconnect Ceramics for SOFCs, J. Power Sources, 2008, 177, p 451-456

7. S.P. Jiang, L. Liu, K.P. Ong, P. Wu, J. Li, and J. Pu, Electrical Conductivity and Performance of Doped $\mathrm{LaCrO}_{3}$ Perovskite Oxides for Solid Oxide Fuel Cells, J. Power Sources, 2008, 176, p 82-89

8. M. Zinkevich, S. Geupel, F. Aldinger, A. Durygin, S.K. Saxena, M. Yang, and Z.-K. Liu, Phase Diagram and Thermodynamics of the $\mathrm{La}_{2} \mathrm{O}_{3}-\mathrm{Ga}_{2} \mathrm{O}_{3}$ System Revisited, J. Phys. Chem. Solids, 2006, 67, p 1901-1907

9. E. Povoden, A.N. Grundy, and L.J. Gauckler, Thermodynamic Reassessment of the Cr-O System in the Framework of Solid Oxide Fuel Cell (SOFC) Research, J. Phase Equilib. Diffus., 2006, 27(4), p 353-362

10. A.T. Dinsdale, SGTE Data for Pure Elements, CALPHAD, 1991, 15(4), p 317-425

11. B. Sundman, B. Jansson, and J.-O. Andersson, The ThermoCalc Databank System, CALPHAD, 1985, 9(2), p 153-190

12. E.M. Savitskii, V.F. Terekhova, and A.V. Kholopov, Phase Diagram for Alloys in the Chromium-Lanthanum System, Russ. J. Inorg. Chem., 1960, 5(3), p 362-363

13. O.M. Barabash and Y.N. Kobal, Crystal Structures of Metals and Alloys (Naukova Dumka, Kiev), 1986, p 264, in Russian

14. V.M. Svechnikov, G.F. Kobzenko, M.V. Kireev, and V.G. Ivancenko, Yttrium and Lanthanum Solubility in Chromium, Dopov. Akad. Nauk. A, 1973, 2, p 167-171, in Ukrainian

15. V.V. Berezutskii, N.I. Usenko, and M.I. Ivanov, Thermochemistry of Binary Alloys of Lanthanum with $3 d$-Transition Metals, Powder Metall. Met. Ceram., 2006, 45(5-6), p 266271

16. F.N. Tavadze, O.I. Mikadze, N.P. Keshelava, and B.P. Bulia, High-Temperature Corrosion of Dilute Chromium-Lanthanum Alloys, Oxid. Met., 1986, 25(5-6), p 335-350

17. S.G. Epstein, A.A. Bauer, and R.F. Dickerson, Solubility Limits of Yttrium and the Lanthanide Rare-Earth Elements in Chromium and Chromium-Iron Alloys, U.S. At. Energy Comm., BMI-1376, 1959

18. S.G. Tresvjatskiy, L.M. Lopato, V.N. Pavlivov, and A.V. Shevchenco, Phase Correlation in the Systems Formed by Oxides of Rare Earths and by Oxide of Chromium, Rev. Int. Hautes. Temp., 1968, 5, p 45-50

19. R. Berjoan, Contribution to the Study of Interactions Between Oxygen and Mixed Lanthanum Oxide and Chromium Oxide(III), or Lanthanum Chromite, Rev. Int. Hautes. Temp., 1976, 13, p 119-135, in French 
20. J.-P. Coutures, J.M. Badie, R. Berjoan, J. Coutures, R. Flamand, and A. Rouanet, Stability and Thermodynamic Properties of Rare Earth Perovskites, High Temp. Sci., 1980, 13, p 331-336

21. M. Foëx, Examination of Freezing Points of Rare Earth Oxides and Chromites, C.R. Acad. Sci. Paris, Gr. 8, 1965, 260, p 6389-6392, in French

22. M. Foëx, Measurement of the Solidification Points of Several Refractory Oxides, Sol. Energy, 1965, 9(1), p 61-67

23. M. Foëx, Comments on the Allotropic Transformations of the Rare Earth Sesquioxides, Z. Anorg. Allg. Chem., 1963, 337, p 313-324, in German

24. M. Foëx, Measurement of the Freezing Points of Refractory Oxides, Rev. Int. Hautes. Temp., 1966, 3, p 309-326, in French

25. D.B. Meadowcroft, Some Properties of Strontium-Doped Lanthanum Chromite, Br. J. Appl. Phys., 1969, 2(2), p 12251233

26. S.A. Suvorov and A.P. Shevchik, Chemical Equilibria Involving Lanthanum Chromite, Refract. Ind. Ceram., 2004, 45(2), p 94-99

27. J.O. Cassedanne, Examination of the Equilibrium Diagram $\mathrm{La}_{2} \mathrm{O}_{3}-\mathrm{Cr}_{2} \mathrm{O}_{3}$, Ann. Acad. Bras. Cienc., 1968, 40(1), p 57-60, in French

28. A.N. Grundy, B. Hallstedt, and L.J. Gauckler, Thermodynamic Assessment of the Lanthanum-Oxygen System, J. Phase Equilib., 2001, 22(2), p 105-113

29. S.B. Tsyrenova, Y.L. Suponitskii, and M.K. Karapetyants, Comparison of Thermal Properties of Oxygen-Containing Compounds of Rare-Earth Elements, Scandium and Yttrium. 2. Thermochemical Properties of Lanthanum Chromates(VI), Zh. Fiz. Khim., 1974, 48(11), p 2705-2707

30. Yu.L. Suponitskii, Thermal Properties and Thermochemistry of Lanthanide Chromates, Russ. Chem. B., Int. Ed., 2005, 54(2), p 294-299

31. H. Schwarz, On the Chromates(V) of the Rare Earths. I Lanthanum Chromate(V), $\mathrm{LaCrO}_{4}$, Z. Anorg. Allg. Chem., 1963, 322(1-2), p 1-14, in German

32. R. Berjoan, J.P. Traverse, and J.P. Coutures, Structural Study and Thermal Decomposition of Lanthanum Based Chromate, Rev. Chim. Miner., 1973, 10, p 309-316, in French

33. A.V. Korobeinikova and A. Reznitskii, Specific Heat, Enthalpy, and Entropy of Lanthanum Chromite Between 298 and $900^{\circ} \mathrm{K}$, High Temp., 1976, 14(4), p 805-806

34. H.E. Höfer and W.F. Kock, Crystal Chemistry and Thermal Behavior in the $\mathrm{La}(\mathrm{Cr}, \mathrm{Ni}) \mathrm{O} 3$ Perovskite System, J. Electrochem. Soc., 1993, 140(10), p 2889-2894

35. N. Sakai and S. Stølen, Heat Capacity and Thermodynamic Properties of Lanthanum(III) Chromate(III): $\mathrm{LaCrO}_{3}$, at Temperatures from $298.15 \mathrm{~K}$. Evaluation of the Thermal Conductivity, J. Chem. Thermodyn., 1995, 27(5), p 493-506

36. V.N. Pavlikov, L.M. Lopato, and S.G. Tresvyatskii, Phase Transformations of Certain Chromites of the Rare Earth Elements, Izv. Akad. Nauk SSSR, Neorg. Mater., 1966, 2(4), p 679-682, in Russian

37. J.S. Ruiz, A.-M. Anthony, and M. Foëx, On the Semiconducting Properties of Lanthanum Chromite, C.R. Acad. Sci. Paris B, 1967, 264, p 1271-1274, in French

38. S. Geller and P.M. Raccah, Phase Transitions in Perovskitelike Compounds of the Rare Earths, Phys. Rev. B, 1970, 2(4), p 1167-1172

39. N. Terao, Some Observations on the Formation and Structure of Lanthanum Chromite, $\mathrm{LaCrO}_{3}$ at Room Temperature, C.R. Acad. Sci. Paris C, 1973, 276, p 5-8, in French

40. S.P. Tolochko, I.F. Kononyuk, V.A. Lyutsko, and Yu.G. Zonov, Phase Transitions in Solid Solutions Based on
Lanthanum Chromite, Izv. Akad. Nauk SSSR, Neorg. Mater., 1985, 23(9), p 1520-1524, in Russian

41. A.C. Momin, E.B. Mirza, and D. Mathews, High-Temperature X-ray Diffractometric Studies of $\mathrm{LaCrO}_{3}$, J. Mater. Sci. Lett., 1991, 10, p 1246-1248

42. T. Hashimoto, N. Tsuzuki, A. Kishi, K. Takagi, K. Tsuda, M. Tanaka, K. Oikawa, T. Kamiyama, K. Yoshida, H. Tagawa, and M. Dokiya, Analysis of Crystal Structure and Phase Transition of $\mathrm{LaCrO}_{3}$ by Various Diffraction Measurements, Solid State Ionics, 2000, 132, p 183-190

43. N. Sakai, K. Oikawa, T. Kamiyama, T. Hashimoto, Y. Shimojyo, and Y. Morii, Structural Phase Transition of Orthorhombic $\mathrm{LaCrO}_{3}$ Studied by Neutron Powder Diffraction, J. Solid State Chem., 2000, 154, p 524-529

44. T. Hashimoto, N. Matsushita, Y. Murakami, N. Kojima, K. Yoshida, H. Tagawa, M. Dokiya, and T. Kikegawa, PressureInduced Structural Phase Transition of $\mathrm{LaCrO}_{3}$, Solid State Commun., 1998, 108(9), p 691-694

45. I. Weinberg and P. Larssen, Electron Paramagnetic Resonance and Antiferromagnetism in $\mathrm{LaCrO}_{3}$, Nature, 1961, 192(4), p 445-446

46. J. Cheng and A. Navrotsky, Enthalpies of Formation of $\mathrm{LaMO}_{3}$ Perovskites $(\mathrm{M}=\mathrm{Cr}, \mathrm{Fe}, \mathrm{Co}$, and Ni), J. Mater. Res., 2005, 20(1), p 191-200

47. H. Satoh, S. Koseki, M. Takagi, W.Y. Chung, and N. Kamegashira, Heat Capacities of $\mathrm{LnCrO}_{3}(\mathrm{Ln}=$ Rare Earth), J. Alloys Compd., 1997, 259, p 176-182

48. N. Sakai, T. Kawada, H. Yokokawa, M. Dokiya, and Y. Takahashi, Heat Capacity Measurement of Lanthanum Chromite by Laser Flash Method, Abstracts of the 27th Symposium on Thermal Analysis and Calorimetry (Kyoto, Japan), November 1991, p 76-77, 1997, in Japanese

49. S. Chen, Z. Hao, F. Li, and G. Zhou, Determination of the Standard Free Energy of Formation of $\mathrm{LaCrO}_{3}$ at $1273 \mathrm{~K}$, Zhongguo Xitu Xuebao, 1987, 5(3), p 19-24, in Chinese

50. A.M. Azad, R. Sudha, and O.M. Sreedharan, Thermodynamic Stability of $\mathrm{LaCrO}_{3}$ by a $\mathrm{CaF}_{2}$-Based E.M.F. Method, J. LessCommon Met., 1990, 166(1), p 57-62

51. Z. Chen, X. Xing, W. Yuan, X. Huang, and H. Li, Thermodynamic Properties of $\mathrm{LaCrO}_{3}$, Rare Met., 2006, 25(5), p 562566

52. M. Dudek, G. Róg, and A. Kozlowska-Róg, Thermodynamic Stability of $\mathrm{LaCrO}_{3}$ and $\mathrm{CaZrO}_{3}$ Using a Solid-State Galvanic Cell Method, Polish J. Chem., 2007, 81, p 23-29

53. D.-H. Peck, M. Miller, D. Kobertz, H. Nickel, and K. Hilpert, Vaporization of $\mathrm{LaCrO}_{3}$ : Partial and Integral Thermodynamic Properties, J. Am. Ceram. Soc., 1996, 79(12), p 3266-3272

54. T. Nakamura, G. Petzow, and L.J. Gauckler, Stability of the Perovskite Phase $\mathrm{LaBO}_{3}(\mathrm{~B}=\mathrm{V}, \mathrm{Cr}, \mathrm{Mn}, \mathrm{Fe}, \mathrm{Co}, \mathrm{Ni})$ in Reducing Atmosphere I. Experimental Results, Mater. Res. Bull., 1979, 14, p 649-659

55. C.P. Khattack and D.E. Cox, Structural Studies of the (La, $\mathrm{Sr}) \mathrm{CrO}_{3}$ System, Mater. Res. Bull., 1977, 12, p 463-472

56. M.N. Iliev, A.P. Litvinchuk, V.G. Hadjiev, Y.-Q. Wang, J. Cmaidalka, R.-L. Meng, Y.-Y. Sun, N. Kolev, and M.V. Abrashev, Raman Spectroscopy of Low-Temperature (Pnma) and High-Temperature $(R \overline{3} c)$ Phases of $\mathrm{LaCrO}_{3}$, Phys. Rev. B, 2006, 74, p 214301-1-214301-7

57. R.H. Mitchell, Perovskites: Modern and Ancient, Almaz Press, Thunder Bay, ON, 2002

58. V.E. Shvaiko-Shvaikovskii, V.P. Popov, and V.G. Gordon, Influence of the Synthesis Conditions on the Electrical Properties of $\mathrm{LaCrO}_{3}, \mathrm{Izv}$. Akad. Nauk SSSR, Neorg. Mater., 1979, 15(8), p 1441-1445, in Russian 
59. T. Akashi, T. Maruyama, and T. Goto, Transport of Lanthanum Ion and Hole in $\mathrm{LaCrO}_{3}$ Determined by Electrical Conductivity Measurements, Solid State Ionics, 2003, 164, p 177-183

60. G.V.S. Rao, B.M. Wanklyn, and C.N.R. Rao, Electrical Transport in Rare Earth Ortho-Chromites, -Manganites and Ferrites, J. Phys. Chem. Solids, 1971, 32, p 345-358

61. A.K. Tripathi and H.B. Lal, Electrical Transport in Light RareEarth Orthochromites, J. Mater. Sci., 1982, 17, p 1595-1609

62. N. Saunders and A.P. Miodownik, Calphad Calculation of Phase Diagrams, Pergamon Materials Series, Vol. 1, Elsevier Science Ltd., 1998, p 94-96

63. E. Povoden, A.N. Grundy, M. Chen, T. Ivas, and L.J. Gauckler, Thermodynamic Assessment of the La-Fe-O System, submitted to J. Phase Equilib. Diffus.

64. C.N.R. Rao, J. Gopalakrishnan, and K. Vidyasagar, Superstructures, Ordered Defects \& Nonstoichiometry in Metal Oxides of Perovskite \& Related Structures, Indian J. Chem., 1984, 23A, p 265-284

65. L.G. Tejuca and J.L.G. Fierro, Structure and Reactivity of Perovskite-Type Oxides, Adv. Catal., 1989, 36, p 243

66. A.N. Grundy, E. Povoden, T. Ivas, and L.J. Gauckler, Calculation of Defect Chemistry Using the CALPHAD Approach, CALPHAD, 2006, 30, p 33-41

67. J.-O. Andersson, A.F. Guillermet, M. Hillert, B. Jansson, and B. Sundman, A Compound-Energy Model of Ordering in a
Phase with Sites of Different Coordination Numbers, Acta Metall., 1986, 34, p 437-445

68. M. Hillert, B. Jansson, and B. Sundman, Application of the Compound-Energy Model to Oxide Systems, Z. Metallkd., 1988, 79(2), p 81-87

69. M. Hillert, The Compound Energy Formalism, J. Alloys Compd., 2001, 320, p 161-176

70. G. Inden, Determination of Chemical and Magnetic Interchange Energies in BCC Alloys. I. General Treatment, $Z$. Metallkd., 1975, 66(10), p 577-582

71. M. Hillert and M. Jarl, A Model of Alloying Effects in Ferromagnetic Metals, CALPHAD, 1978, 2(3), p 227-238

72. M. Chen, B. Hallstedt, and L.J. Gauckler, Thermodynamic Assessment of the Co-O System, J. Phase Equilib., 2003, 24(3), p 212-227

73. E. Povoden, "Thermodynamic Database of the La-Sr-Mn-CrO Oxide System and Applications to Solid Oxide Fuel Cells," Thesis, ETH Zurich, 2008

74. M. Hillert, B. Jansson, B. Sundman, and J. Ågren, A TwoSublattice Model of Molten Solutions with Different Tendency of Ionization, Metall. Trans. A, 1985, 16A, p 261-266

75. B. Sundman, Modification of the Two-sublattice Model for Liquids, CALPHAD, 1991, 15, p 109-119

76. R. Akila and K.T. Jacob, The Mobility of Oxygen Ions in $\mathrm{CaF}_{2}$, J. Appl. Electrochem., 1990, 20, p 294-300 